Supporting information for

\title{
Identifying the Molecular Structures of Intermediates for Optimizing the Fabrication of High-Quality Perovskite Films
}

Jing Cao, ${ }^{1, \dagger}$ Xiaojing Jing, ${ }^{1, \dagger}$ Juanzhu Yan, ${ }^{1}$ Chengyi Hu, ${ }^{1}$ RuihaoChen, ${ }^{1}$ Jun Yin, ${ }^{1,2}$ Jing Li, ${ }^{2, *}$ Nanfeng Zheng ${ }^{1, *}$

${ }^{1}$ State Key Laboratory for Physical Chemistry of Solid Surfaces, Collaborative Innovation Center of Chemistry for Energy Materials, and Engineering Research Center for Nano-Preparation Technology of Fujian Province, College of Chemistry and Chemical Engineering, Xiamen University, Xiamen 361005, China.

${ }^{2}$ Collaborative Innovation Center for Optoelectronic Semiconductors and Efficient Devices, Pen-Tung Sah Institute of Micro-Nano Science and Technology, Xiamen University, Xiamen 361005, China.
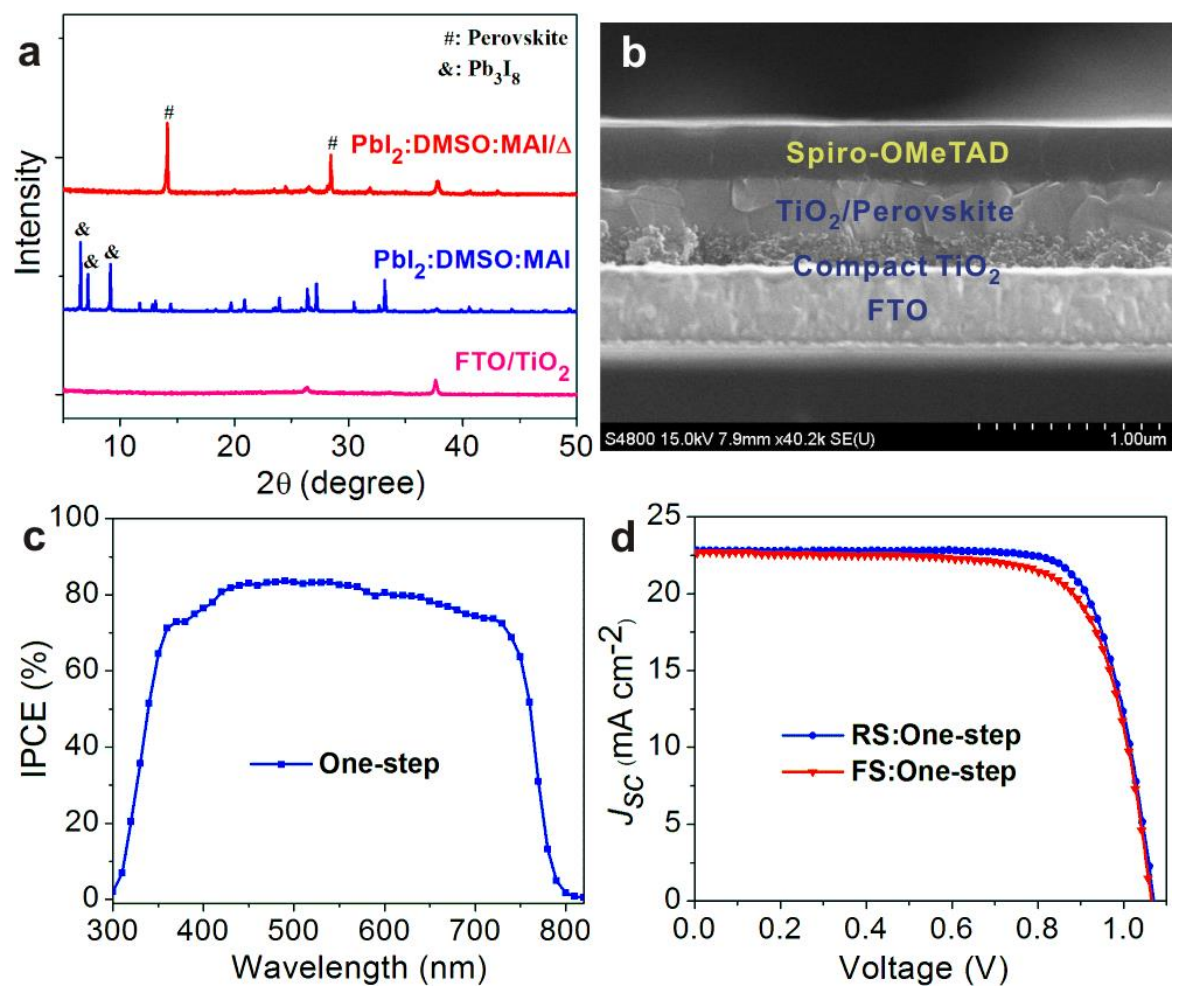

Figure S1. (a) The XRD pattern variations of the perovskite films fabricated by one-step (Pbl 2 :DMSO:MAI) method followed with annealing (Pbl 2 :DMSO:MAI/ $\Delta$ ). Cross-sectional SEM image (b), IPCE value (c) and the best $J-V$ characteristics measured with forward (FS) and reverse (RS) scans (d). 

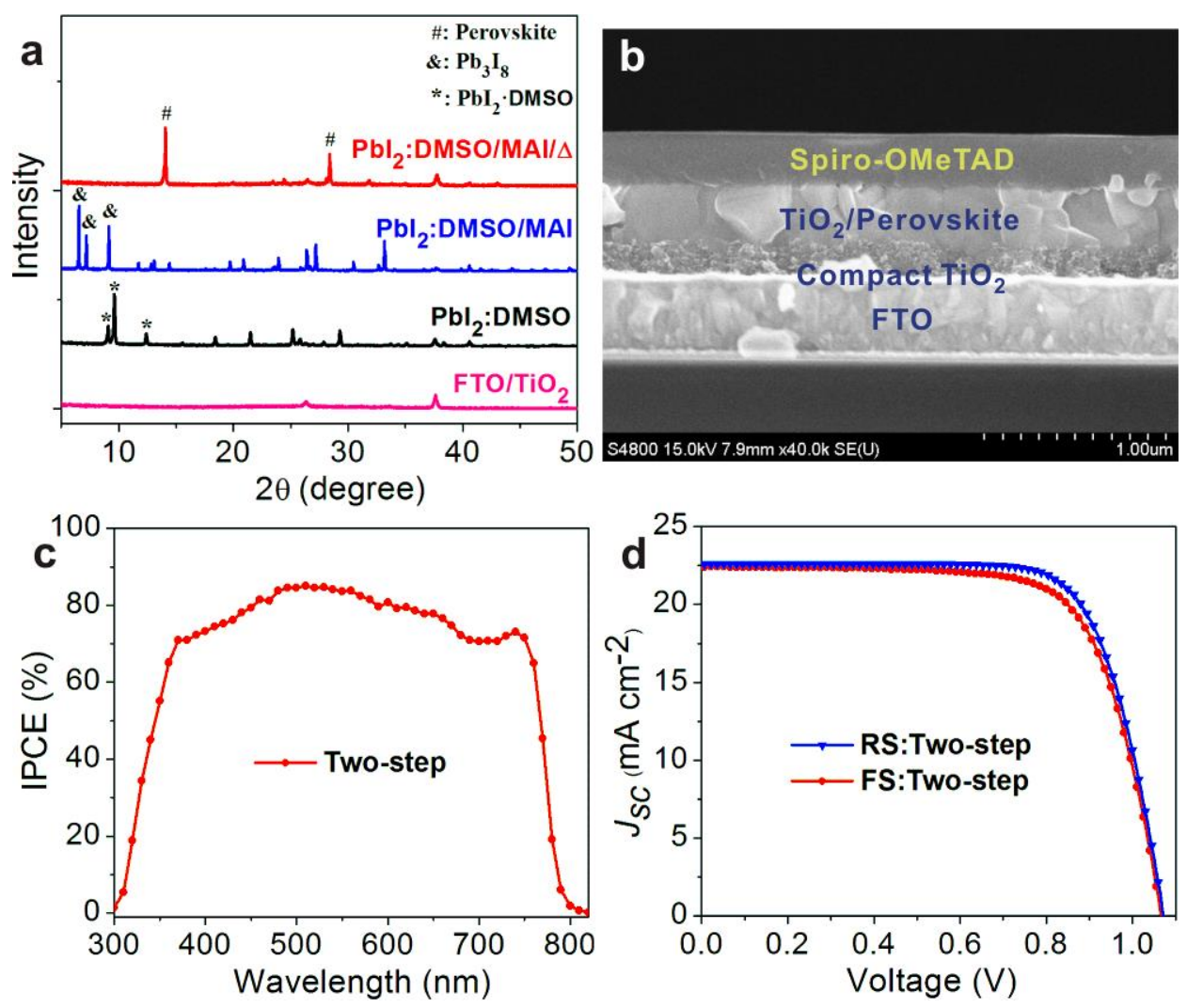

Figure S2. (a) The XRD pattern variations of the perovskite films fabricated by two-step $\left(\mathrm{Pbl}_{2}: \mathrm{DMSO} / \mathrm{MAl}\right)$ method followed with annealing $\left(\mathrm{Pbl}_{2}: \mathrm{DMSO} / \mathrm{MAl} / \Delta\right)$. Cross-sectional SEM image (b), IPCE value (c) and the best $J-V$ characteristics measured with forward (FS) and reverse (RS) scans (d). 


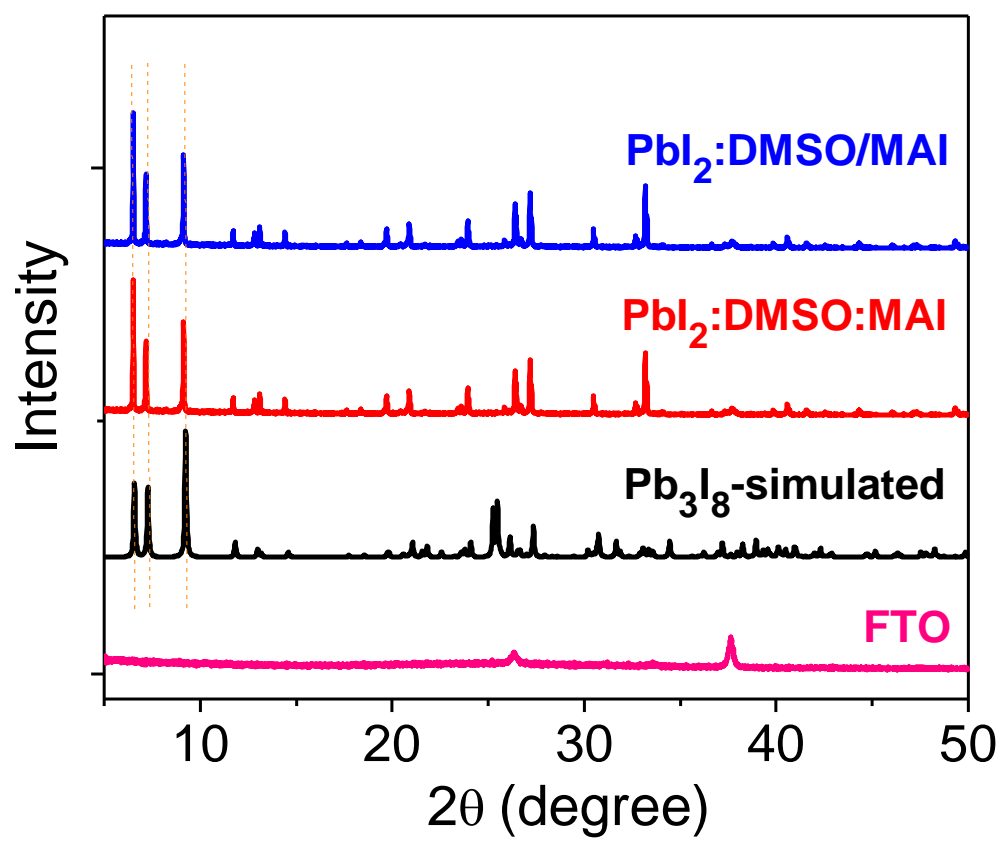

Figure S3. The XRD spectra of the perovskite films before annealing obtained by one-step ( $\left.\mathrm{Pbl}_{2}: \mathrm{DMSO}: \mathrm{MAI}\right)$ and two-step ( $\left.\mathrm{Pbl}_{2}: \mathrm{DMSO} / \mathrm{MAl}\right)$ methods, and the simulated value of $\mathrm{Pb}_{3} \mathrm{l}_{8}$ by the crystal structure.

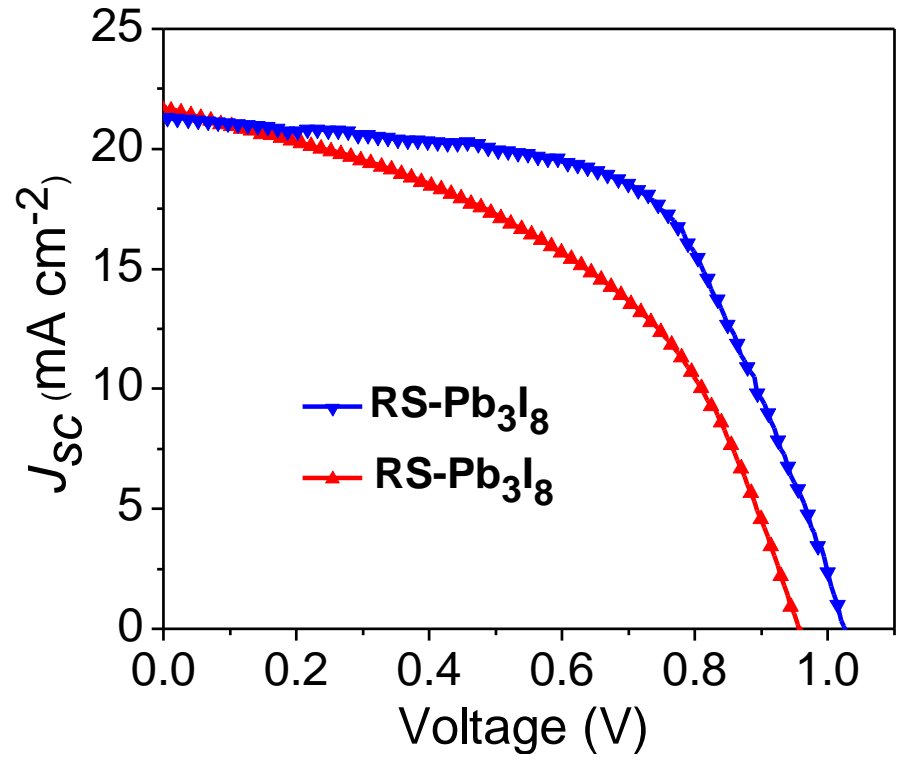

Figure S4. The $J-V$ characteristics of the best PSC device based on $\mathrm{Pbl}_{3} \mathrm{I}_{8}$ precursor. 

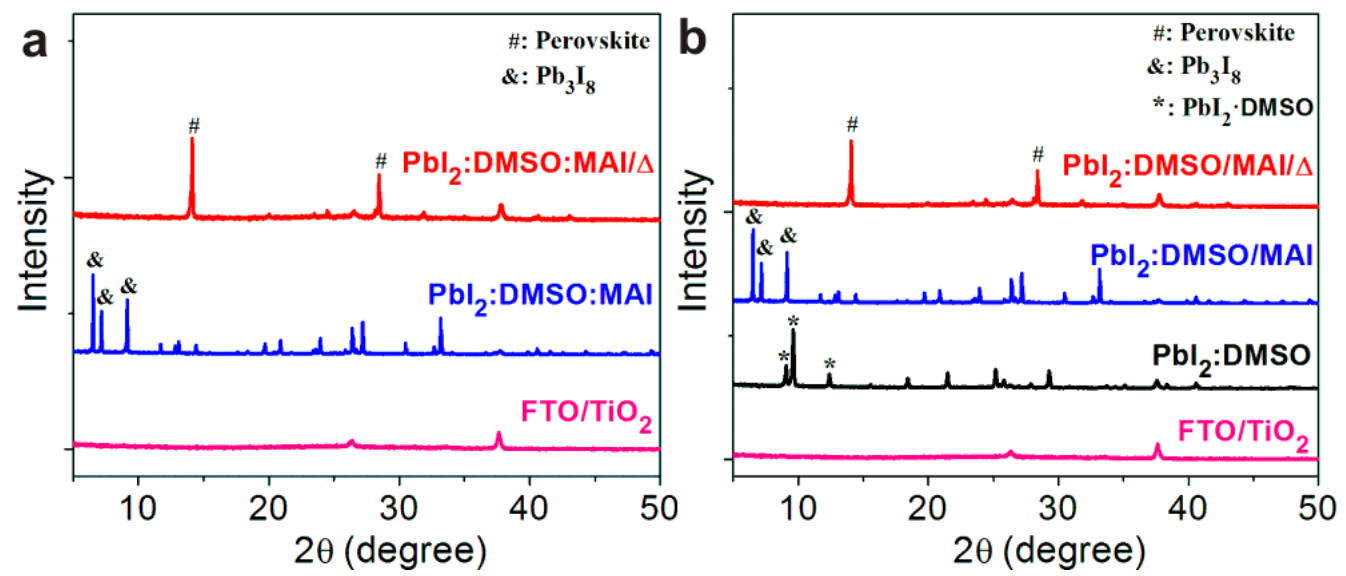

Figure S5. The XRD pattern variations of the formation process of perovskite films fabricated by (a) one-step (Pbl $2: D M S O: M A l)$ and (b) two-step ( $\mathrm{Pbl}_{2}: \mathrm{DMSO} / \mathrm{MAl}$ ) methods.

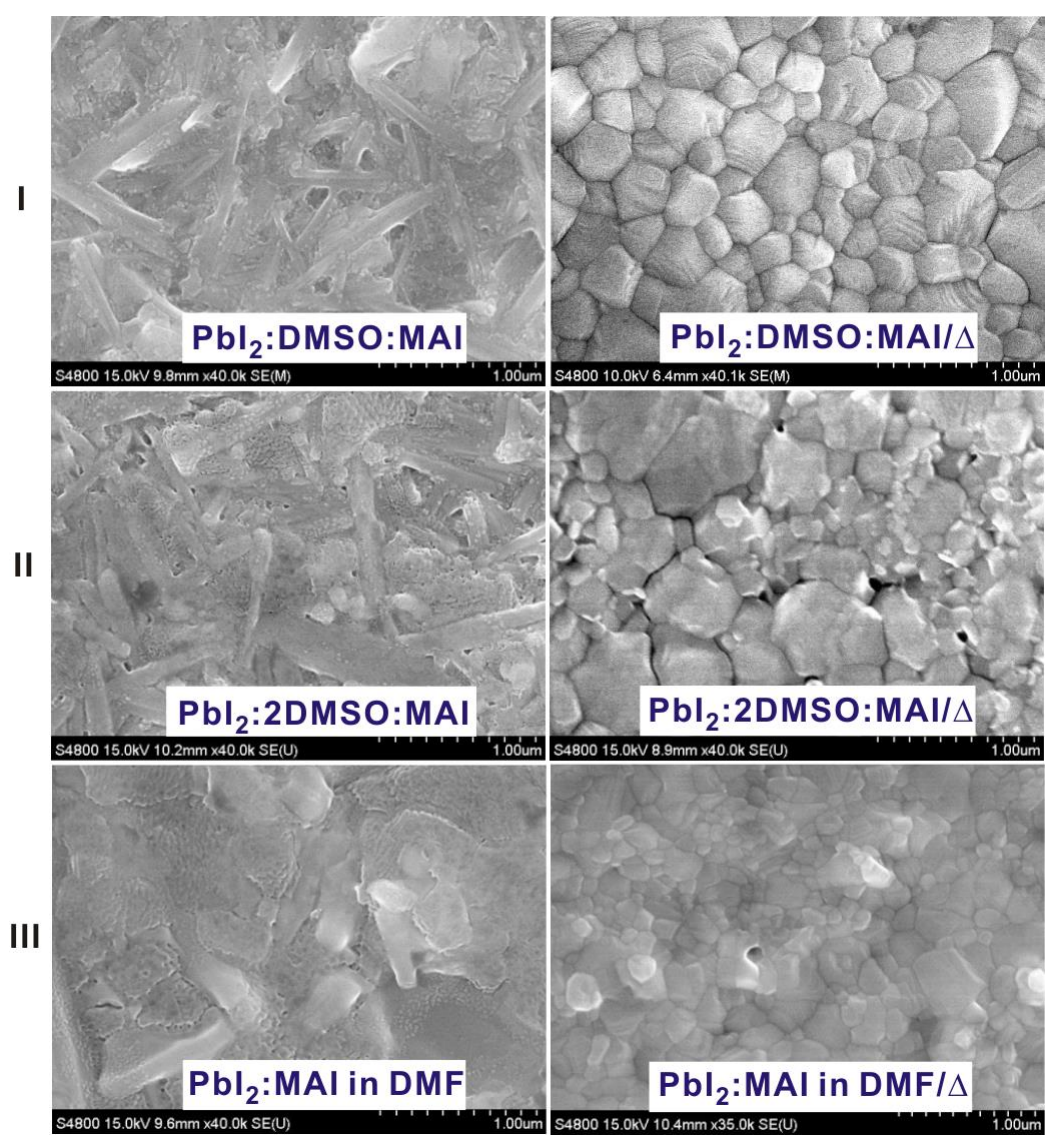

Figure S6. SEM images of the films produced by the reaction between MAI and $\mathrm{Pbl}_{2}$ :DMSO (row I) and $\mathrm{Pbl}_{2}$ :2DMSO (row II) before and after annealing $(\Delta)$, as comparisons to those (row III) without the introduction of DMSO. 

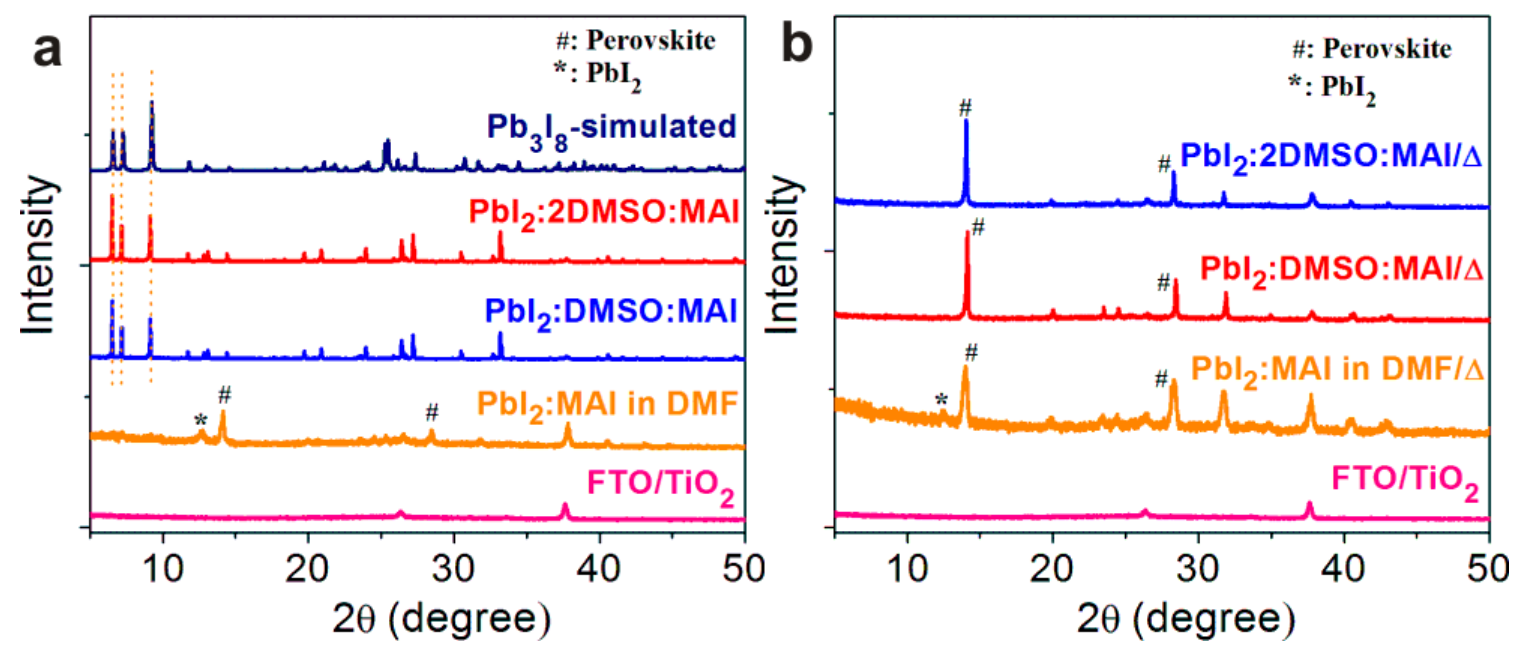

Figure S7. The XRD pattern variations of the perovskite films fabricated byone-step method with different ratio of $\mathrm{Pbl}_{2}$-DMSO before (a) and after(b) annealing $(\Delta)$.

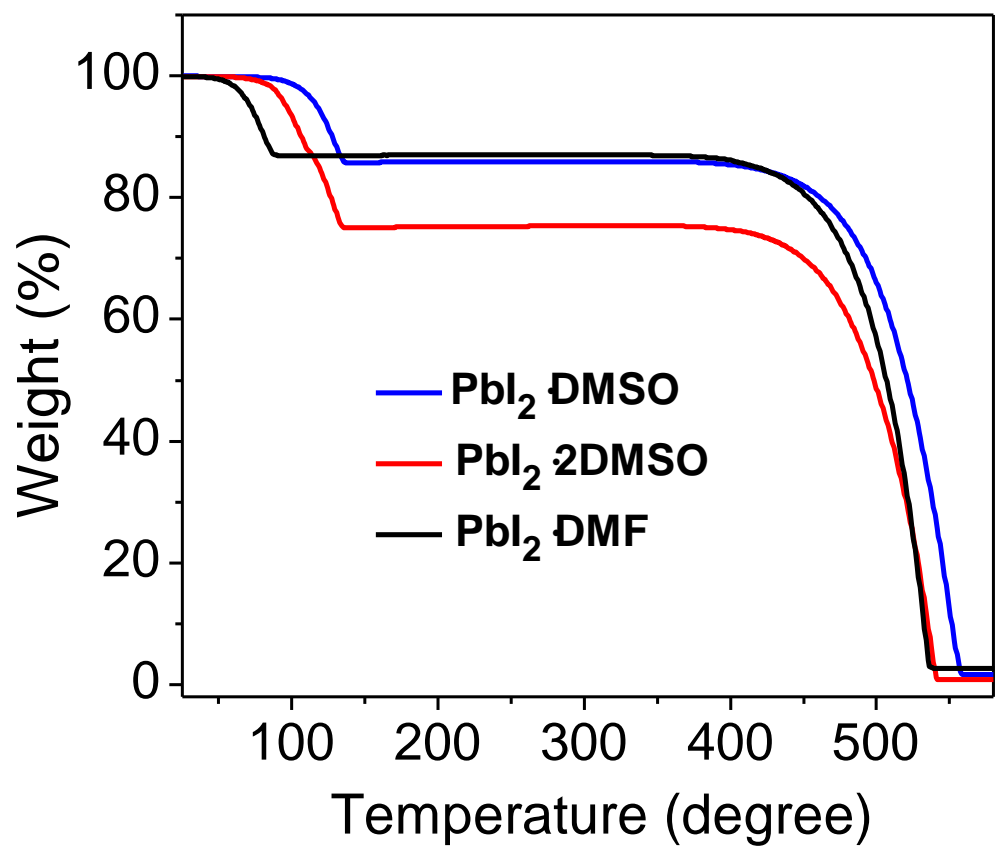

Figure S8. The TGA spectra of $\mathrm{Pbl}_{2} \cdot \mathrm{DMF}, \mathrm{Pbl}_{2} \cdot \mathrm{DMSO}$ and $\mathrm{Pbl}_{2} \cdot 2 \mathrm{DMSO}$ powder samples. 


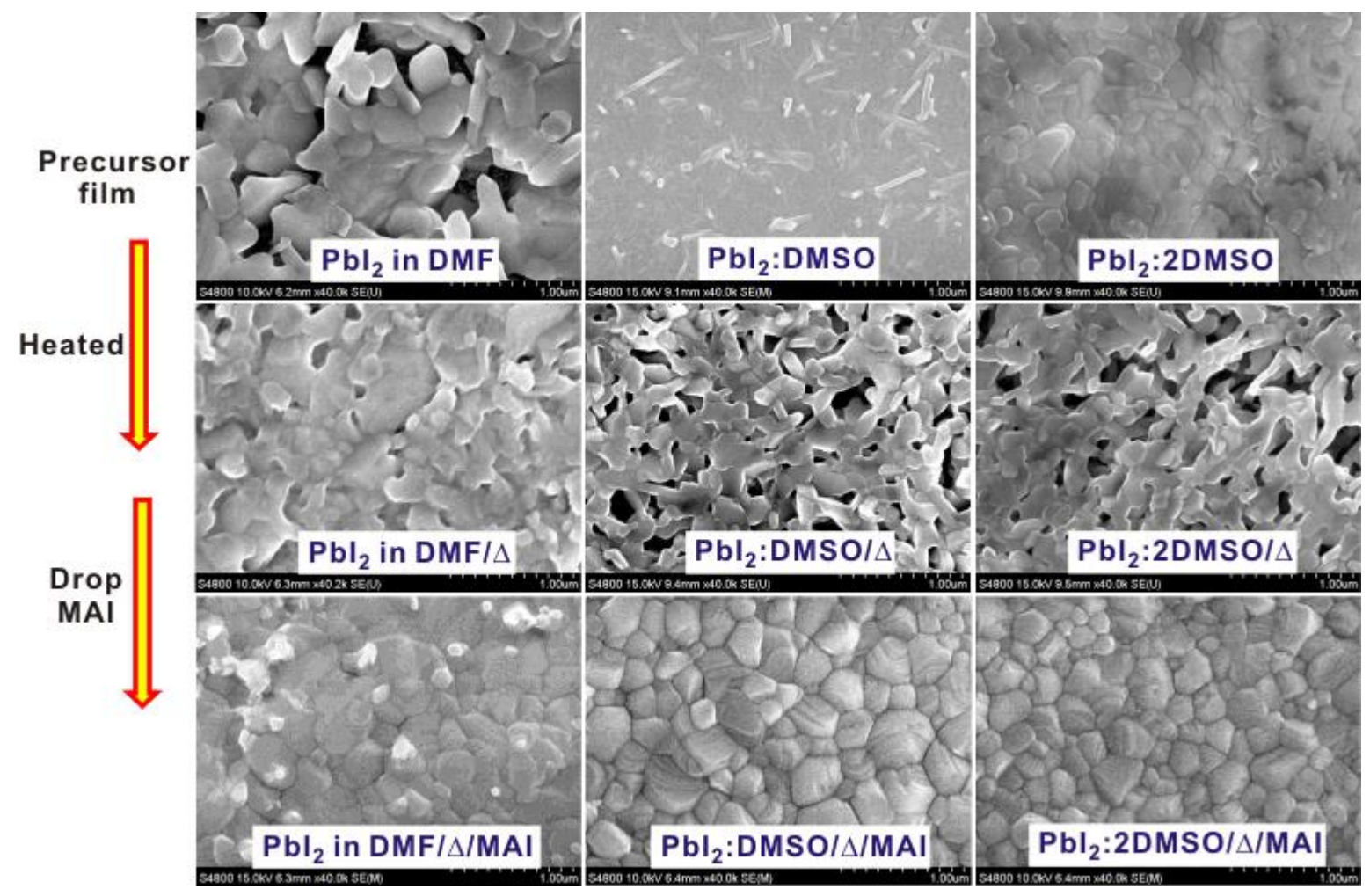

Figure S9. SEM images of the $\mathrm{Pbl}_{2}$ precursor films before and after annealing $(\Delta)$ at $80{ }^{\circ} \mathrm{C}$ for 5 min, and then reacted with MAI.
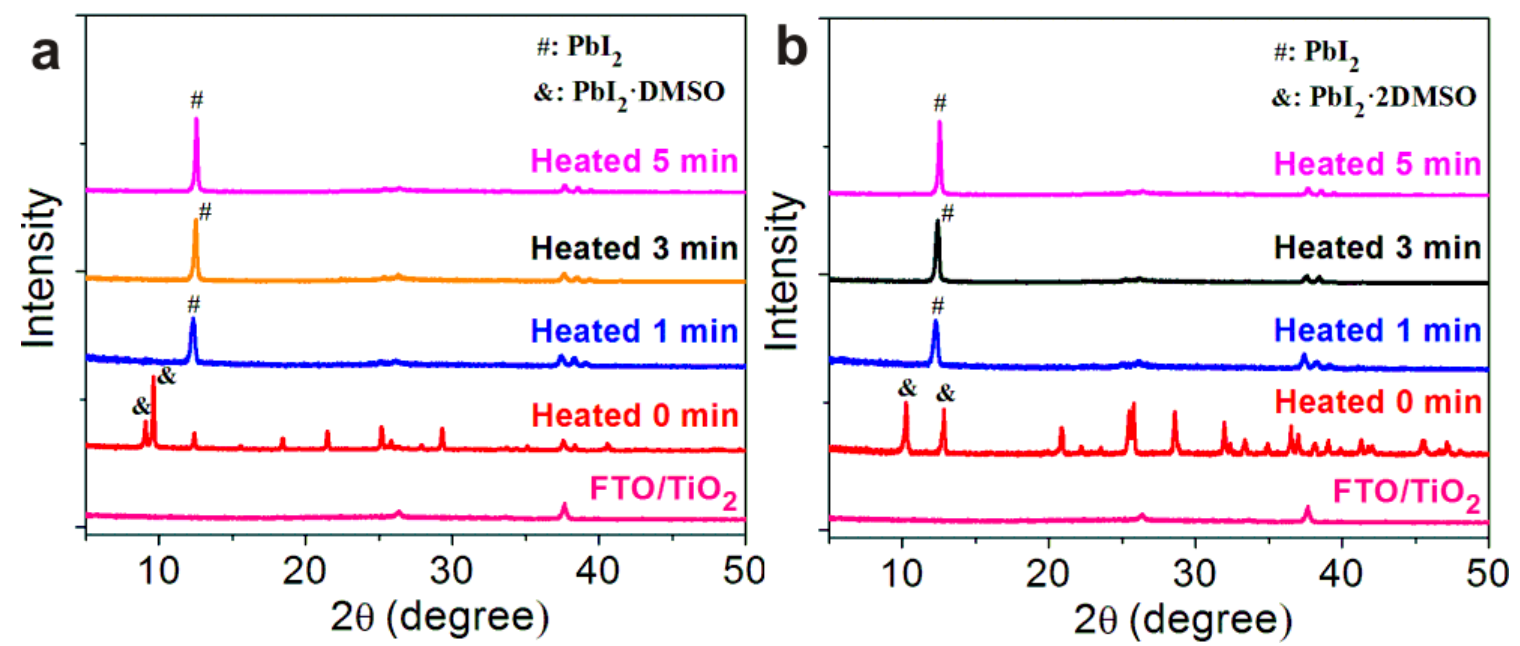

Figure S10. XRD pattern variations of the heated $\mathrm{Pbl}_{2}: \mathrm{DMSO}(\mathrm{a})$ and $\mathrm{Pbl}_{2}: 2 \mathrm{DMSO}$ (b) films for different time. 


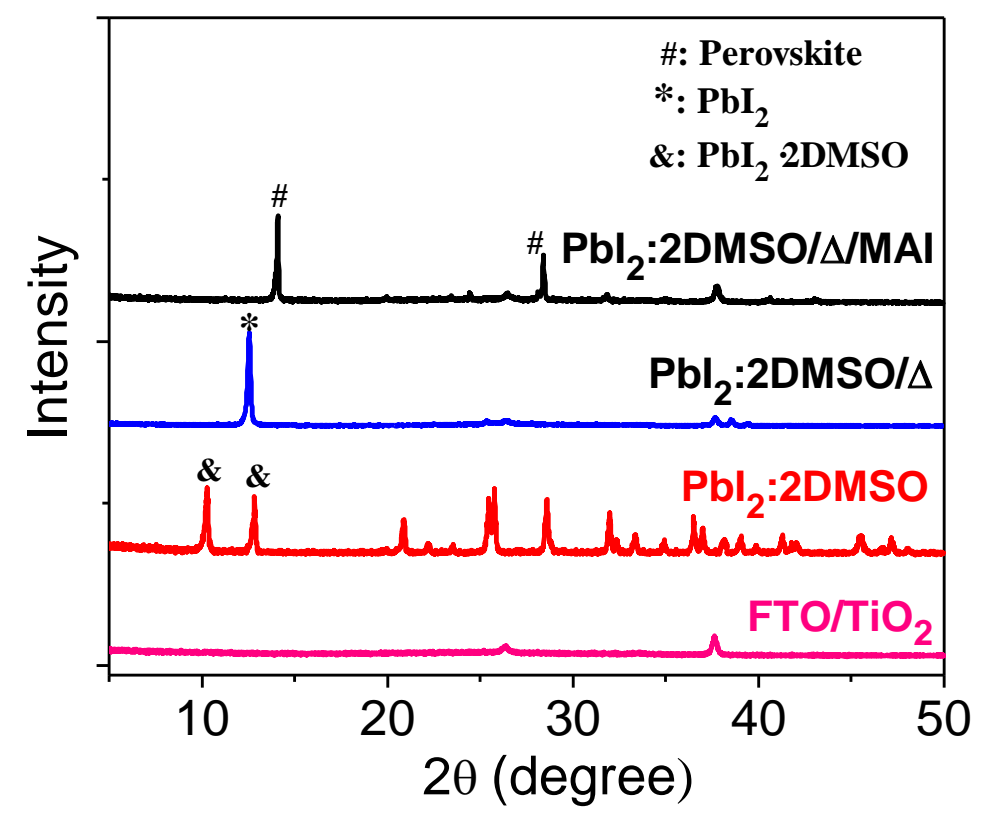

Figure S11. XRD spectra of $\mathrm{Pbl}_{2} \cdot 2 \mathrm{DMSO}$ films before and after annealing $(\Delta)$ at $80^{\circ} \mathrm{C}$ for $5 \mathrm{~min}$, and obtained perovskite film by reacting with MAI.

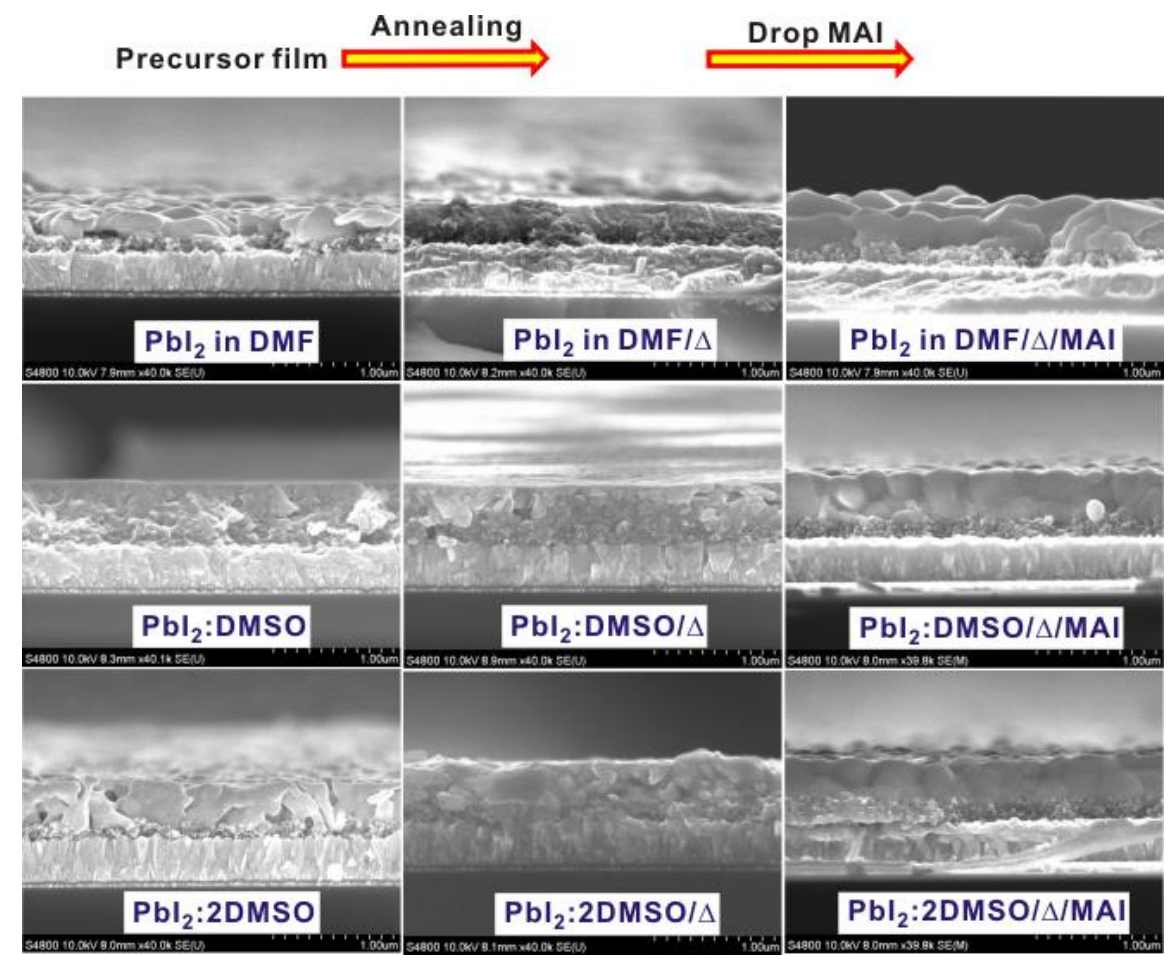

Figure S12. Cross-sectional SEM images of the $\mathrm{Pbl}_{2}$ precursor films before and after heating $(\Delta)$ at $80{ }^{\circ} \mathrm{C}$ for $5 \mathrm{~min}$, and then reacting with $\mathrm{MAl}$. 

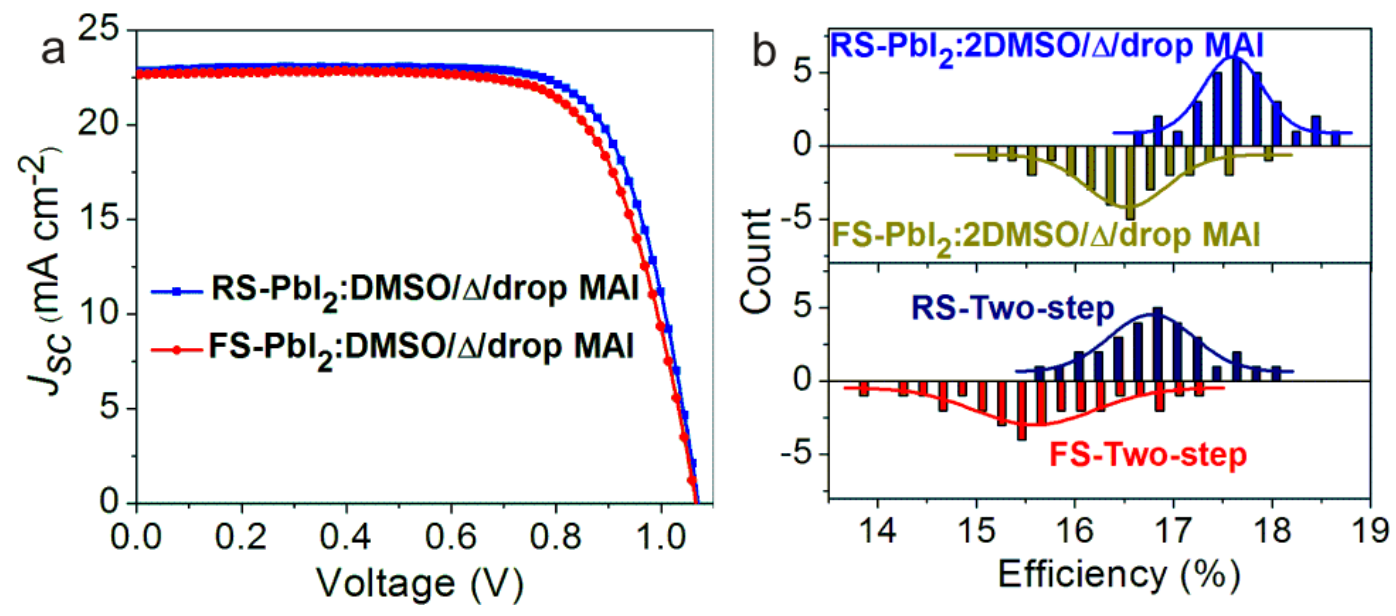

Figure S13. The the best $J$ - $V$ data (a) and histogram of efficiencies among 30 PSCs devices (b) obtained by $\mathrm{Pbl}_{2}: 2 \mathrm{DMSO}$ precursor measured by forward (FS) and reverse (RS) scans.

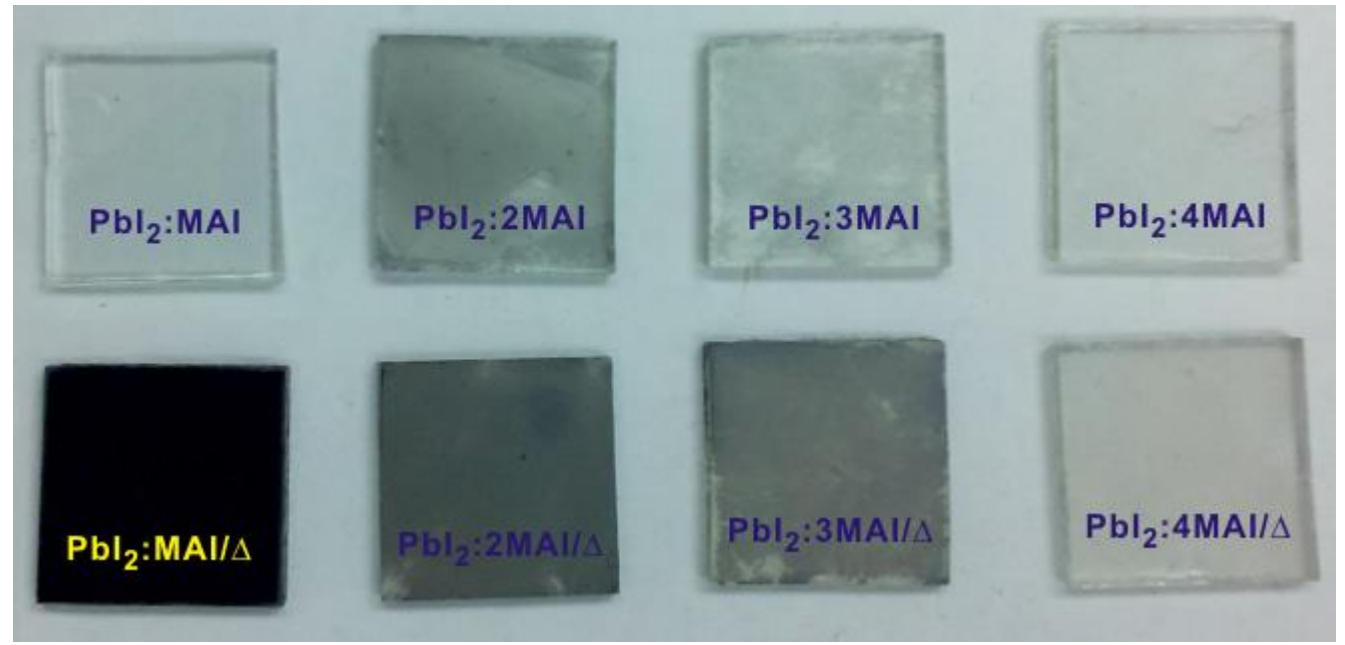

Figure S14. Images of the films with different $\mathrm{Pbl}_{2}-\mathrm{MAl}$ ratios before (Top row) and after (Bottom row) annealing. 


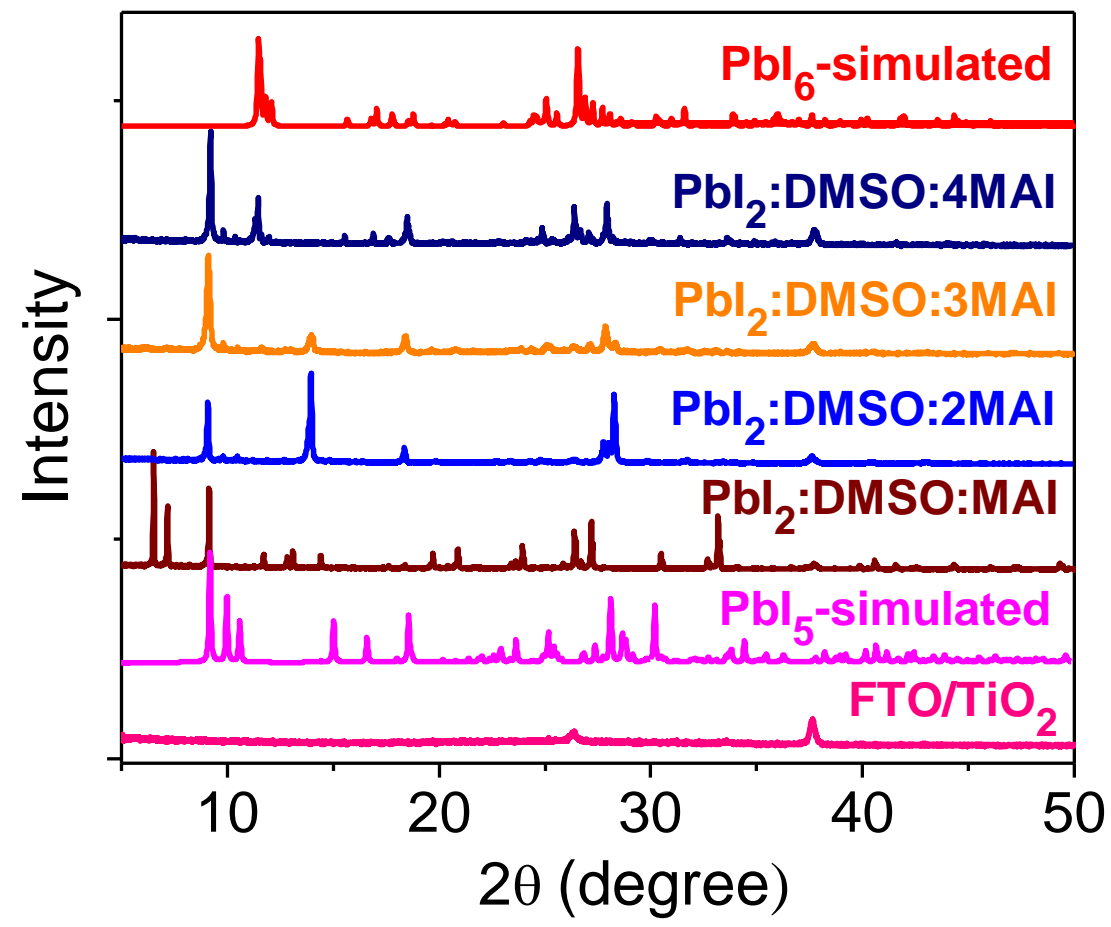

Figure S15. The XRD spectra of the films with different $\mathrm{Pbl}_{2}-\mathrm{MAI}$ ratios before annealing. When the $\mathrm{MAl} / \mathrm{Pbl}_{2}$ ratio was 1 , the peaks were described to $\mathrm{Pb}_{3} \mathrm{l}_{8}$ sample. The $\mathrm{MAI} / \mathrm{Pbl}_{2}$ ratio came to 2, peaks belonging to perovskite at $14.0^{\circ}$ and $28.2^{\circ}$ appeared, while $\mathrm{Pbl}_{5}$ phase with peaks at $9.2^{\circ}, 9.8^{\circ}$ and $10.6^{\circ}$ were also observed. With $\mathrm{MAl} / \mathrm{Pbl}_{2}$ ratio further increased to 3 and 4 , the perovskite phase slowly disappeared and $\mathrm{Pbl}_{6}$ with the peaks at $11.5^{\circ}$ and $26.5^{\circ}$ came out. 


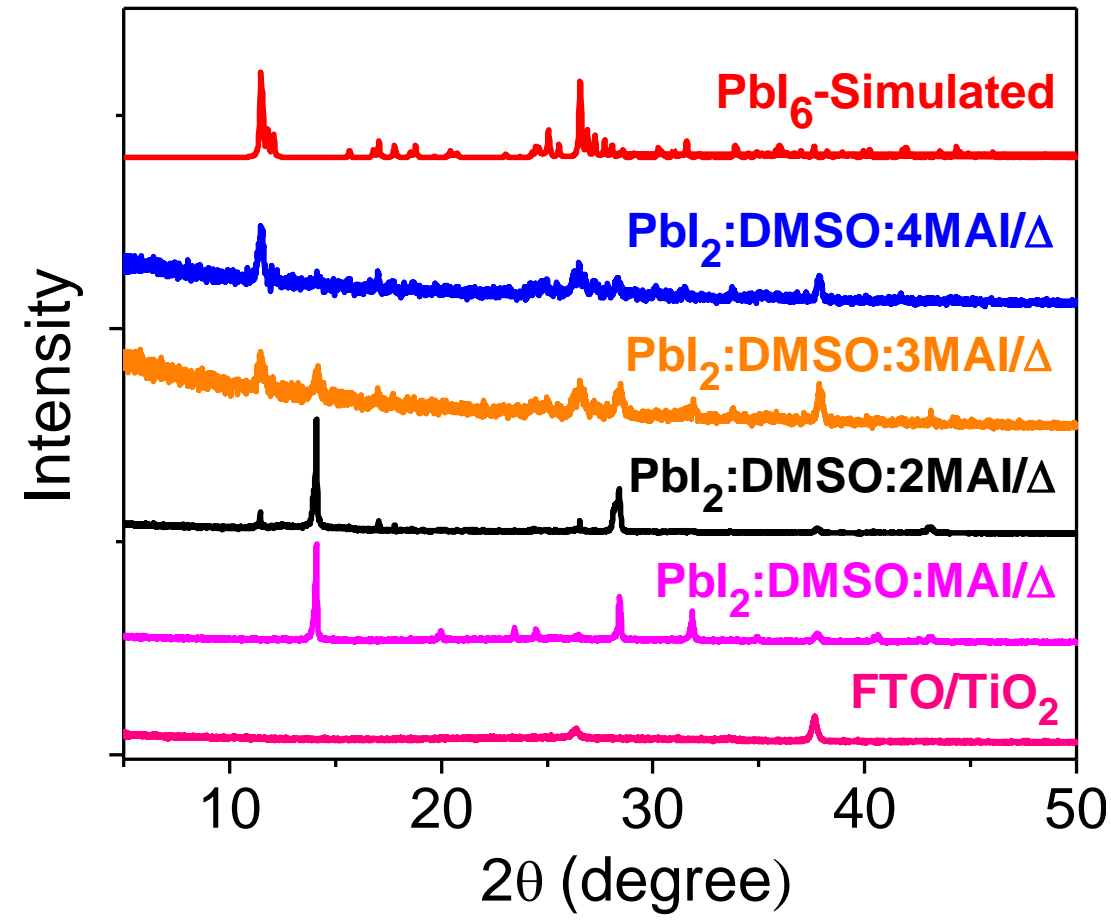

Figure S16. XRD spectra of the films with different $\mathrm{Pbl}_{2}-\mathrm{MAI}$ ratios after annealing. $\mathrm{Pbl}_{6}$ phase with the peaks at $11.5^{\circ}$ and $26.5^{\circ}$ can be identified in all films prepared with excess MAI. 


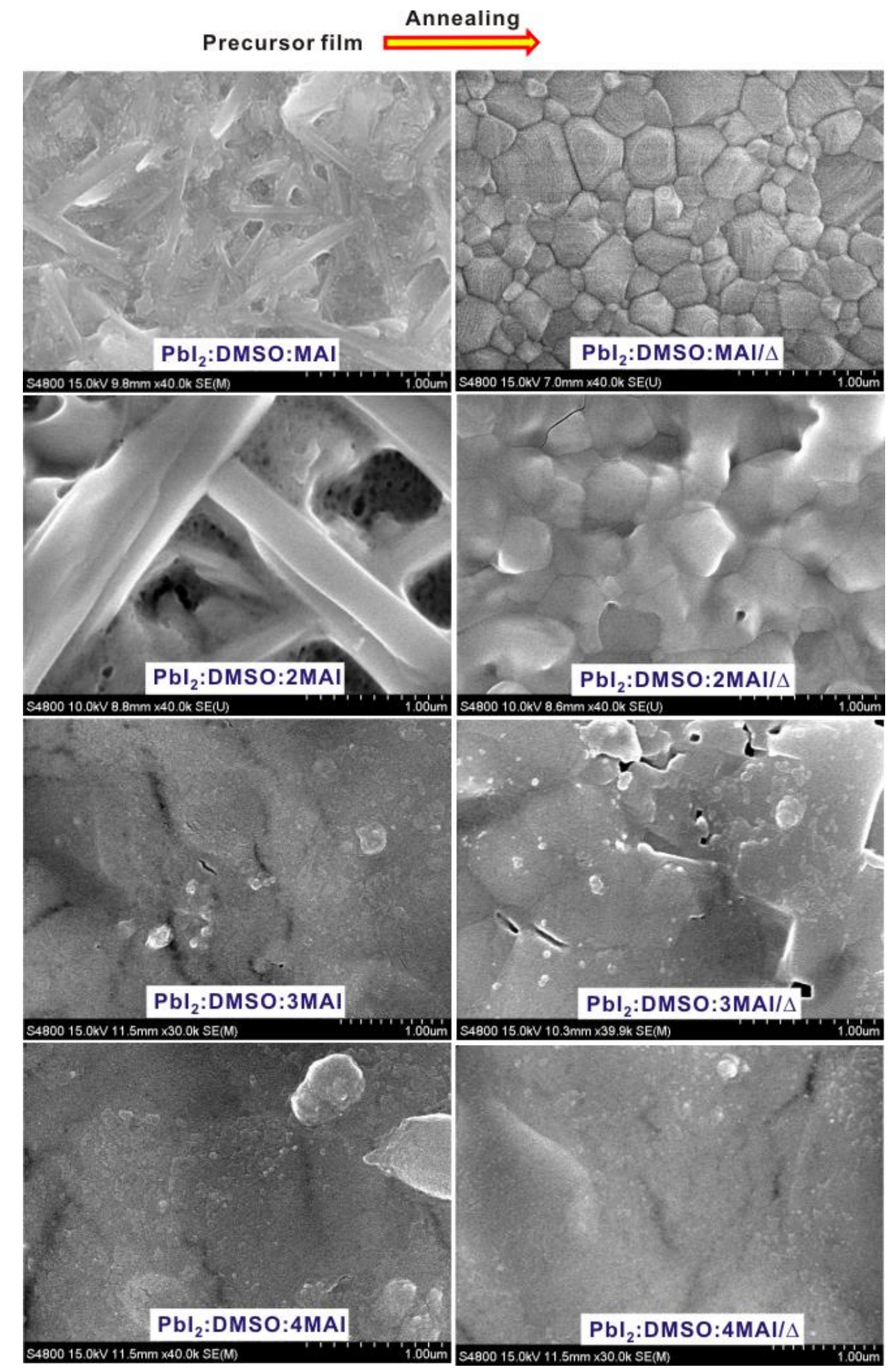

Figure S17. SEM images of the films with different $\mathrm{Pbl}_{2}-\mathrm{MAI}$ ratios. 

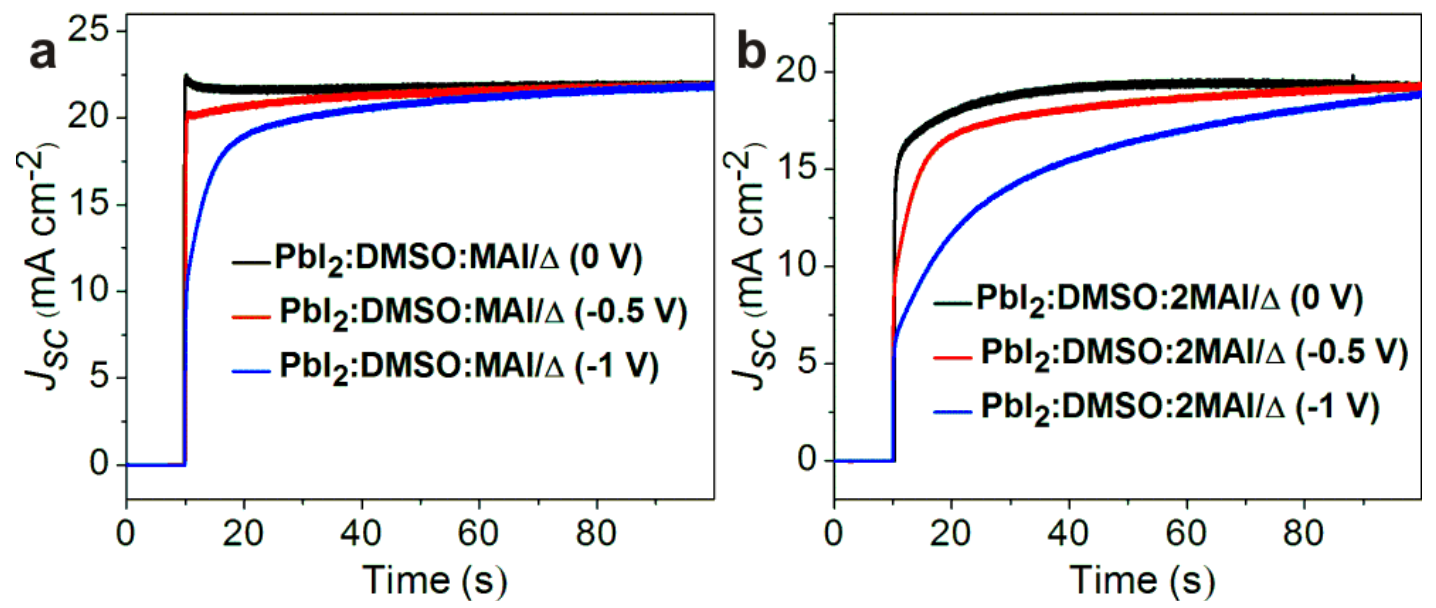

Figure S18. The dynamic $J_{s c}$ transient processes when switching bias voltage from $V_{o c}$ to $0 \mathrm{~V}$ for unpoled and poled samples of $\mathrm{Pbl}_{2}$ :DMSO:MAI (a) and $\mathrm{Pbl}_{2}$ :DMSO:2MAI (b). The PSC devices were electrically poled for $30 \mathrm{~s}$ under dark condition with $-0.5 \mathrm{~V}$ or $-1 \mathrm{~V}$, and then short-circuited for $1 \mathrm{~min}$ to eliminate the electric-charge accumulation before $\mathrm{J}-V$ measurement. The dynamic $J_{s c}$ values with the variation of time were then recorded. 


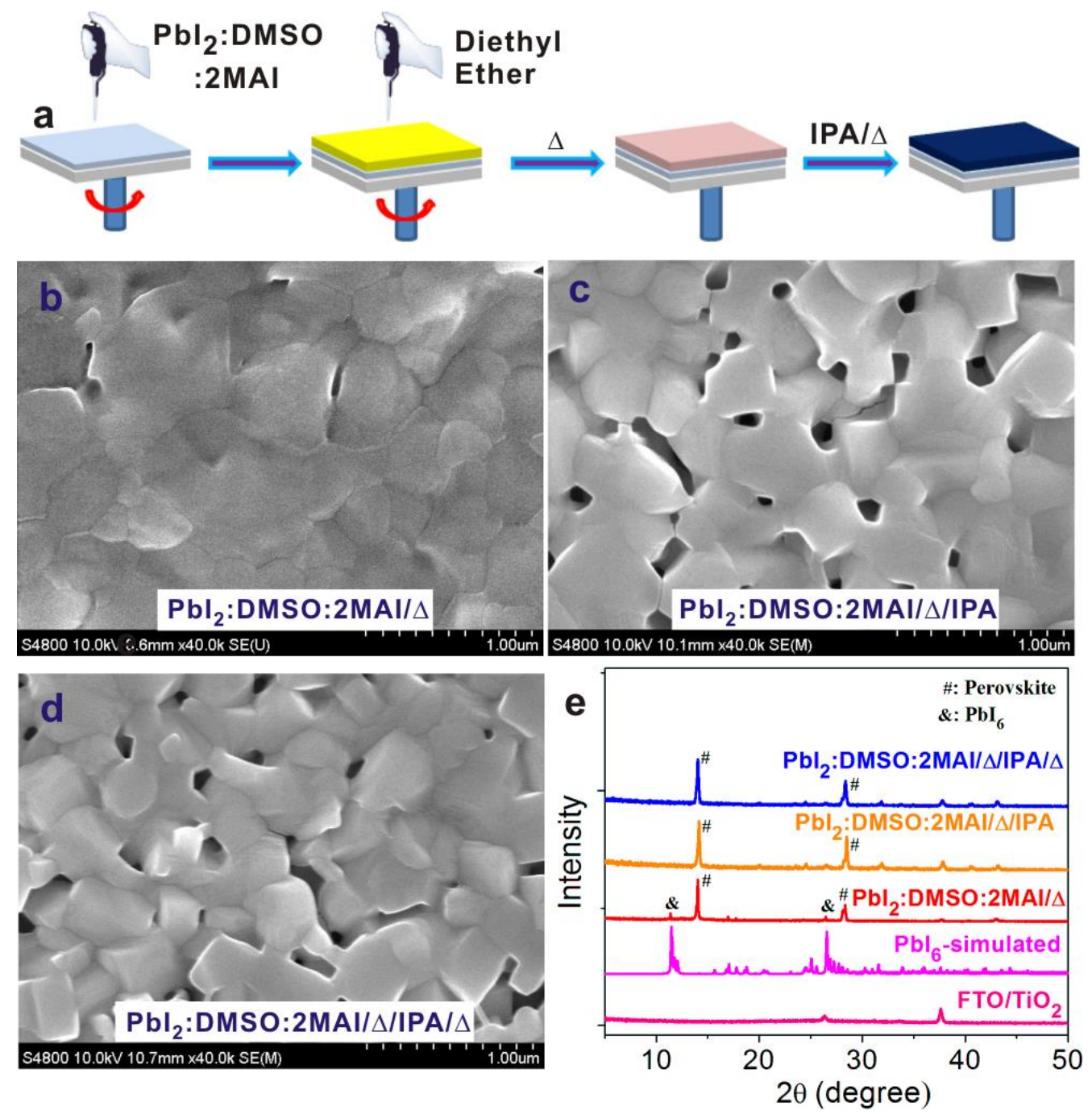

Figure S19. (a) The schematic illustrationof cell fabrication process. SEM images of the films based on annealed $\mathrm{Pbl}_{2}$ :DMSO:2MAI sample (b) followed by IPA washing (c) and then annealing (d). The variations of the XRD patterns of films prepared by above preparation processes (e). 

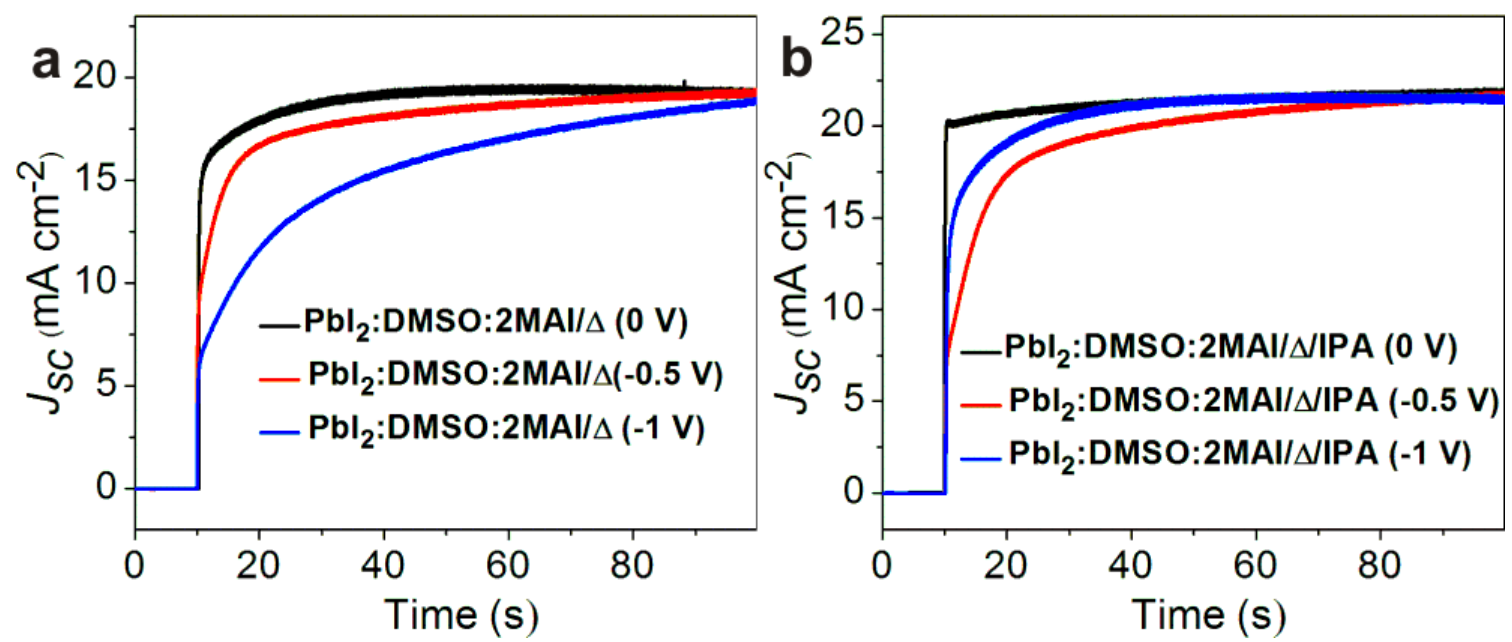

Figure S20. The dynamic $J_{s c}$ transient processes when switching bias voltage from $V_{o c}$ to $0 \mathrm{~V}$ for unpoled and poled devices of $\mathrm{Pbl}_{2}$ :DMSO:2MAI (a) and $\mathrm{Pbl}_{2}$ :DMSO:2MAI/IPA (b). The PSC devices were electrically poled for $30 \mathrm{~s}$ under dark condition with $-0.5 \mathrm{~V}$ or $-1 \mathrm{~V}$, and then short-circuited for $1 \mathrm{~min}$ to eliminate the electric-charge accumulation before $\mathrm{J}-V$ measurement. The dynamic $J_{s c}$ values with the variation of time were then recorded.

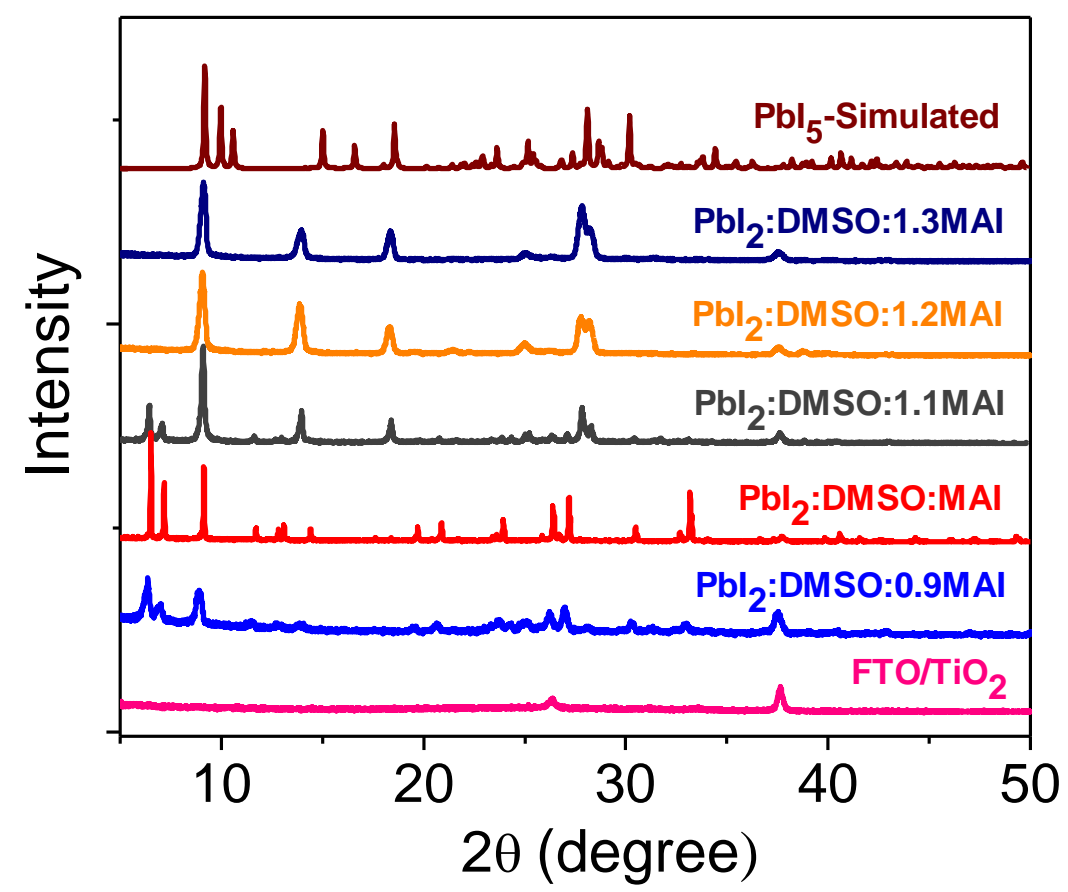

Figure S21. The XRD spectra of the films with different $\mathrm{Pbl}_{2}-\mathrm{MAI}$ ratios before annealing. When the $\mathrm{MAl} / \mathrm{Pbl}_{2}$ ratio was below 1.1 , the peaks were described to $\mathrm{Pb}_{3} \mathrm{l}_{8}$ samples. At the $\mathrm{MAl} / \mathrm{PbI}_{2}$ ratio above 1.2,the $\mathrm{Pb}_{3} \mathrm{I}_{8}$ peaks disappeared and I-rich phases were observed. 


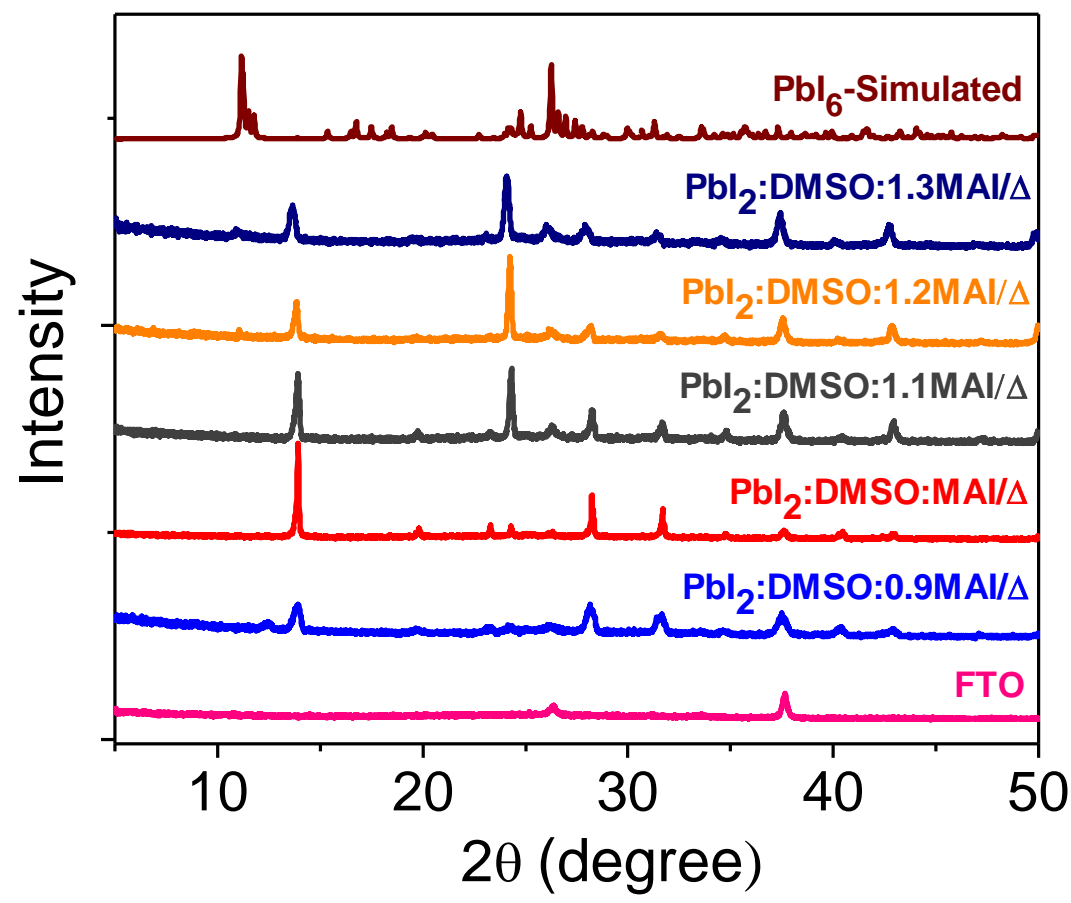

Figure S22. The XRD spectra of the films with different $\mathrm{Pbl}_{2}-\mathrm{MAI}$ ratios after annealing. When the $\mathrm{MAl} / \mathrm{Pbl}_{2}$ ratio was above1.2, $\mathrm{Pbl}_{6}$ phase with the peaks at $11.5^{\circ}$ was clearly observed.

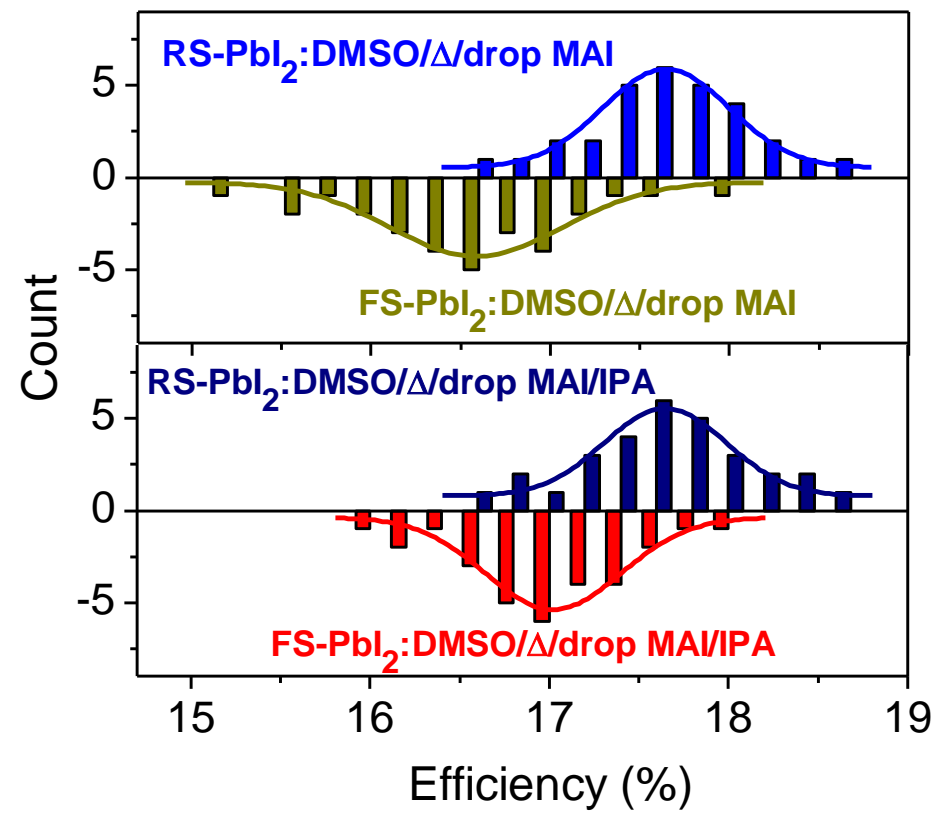

Figure S23. Comparison of the performance distributions of 30 individual devices based on the mesoporous $\mathrm{Pbl}_{2}$ with or without IPA washing measured by forward (FS) and reverse (RS) scans. 


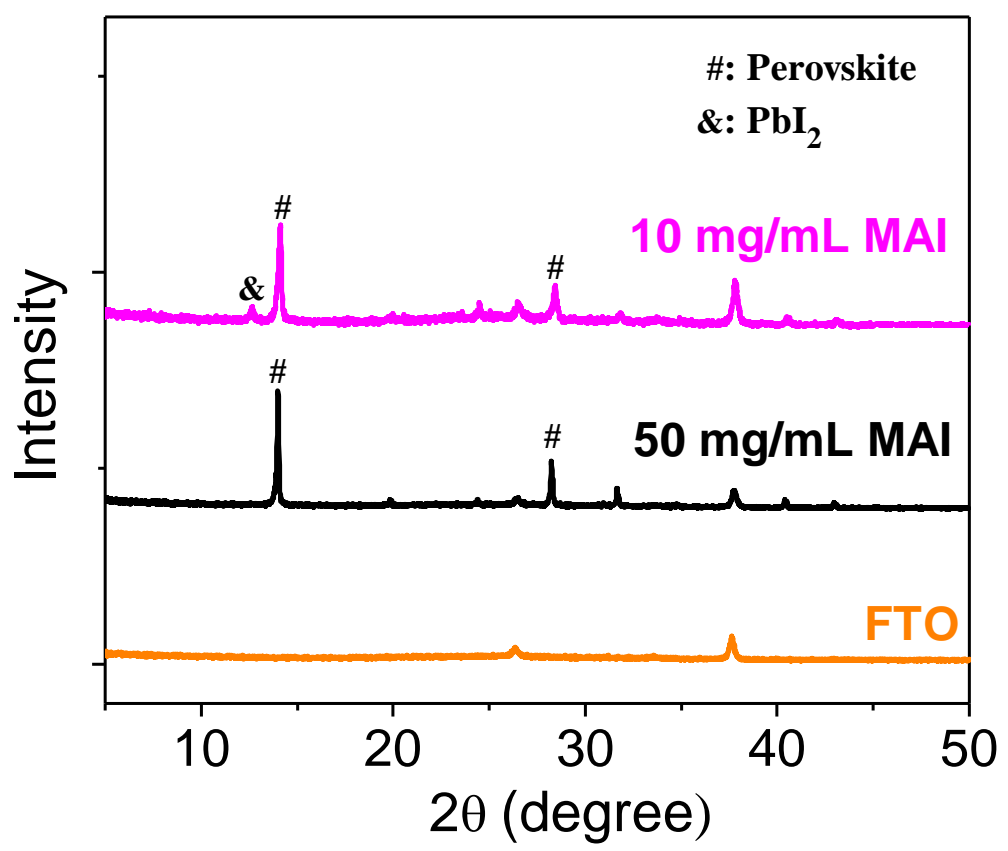

Figure S24. The XRD patterns of perovskite films by reaction of mosoporous $\mathrm{Pbl}_{2}$ with different concentrations of MAI.

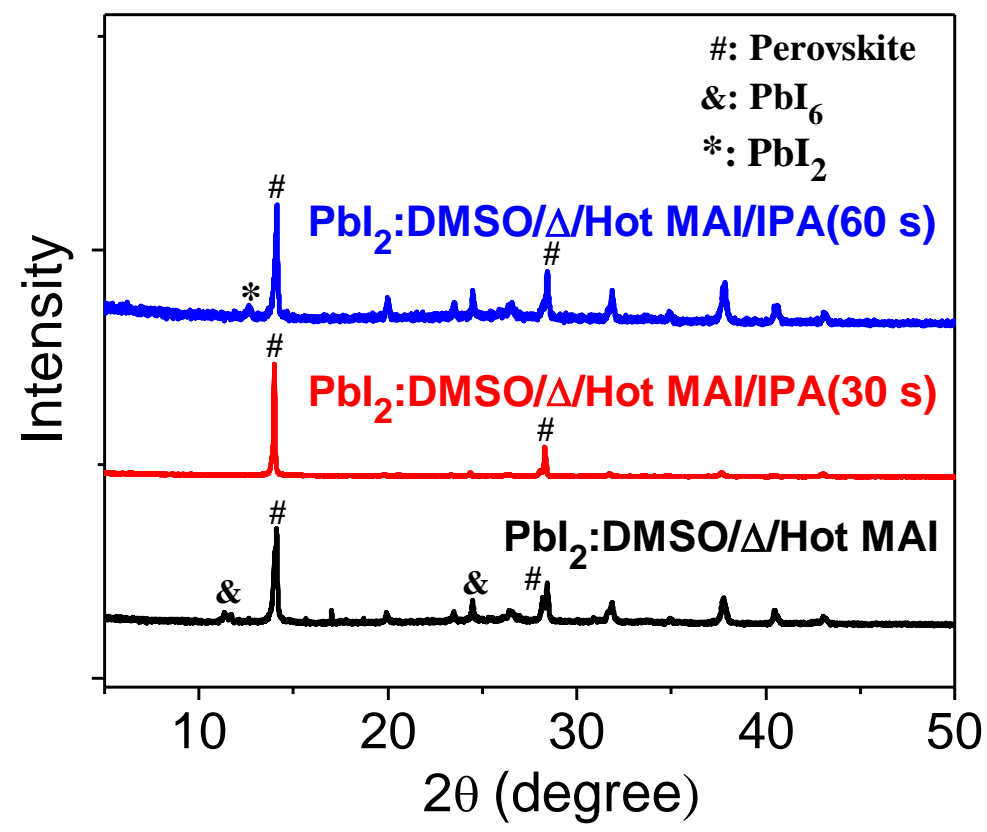

Figure S25. The XRD patterns of perovskite films obtained by reaction of mosoporous $\mathrm{Pbl}_{2}$ with hot MAI, and then immersed into IPA solution with different time. 

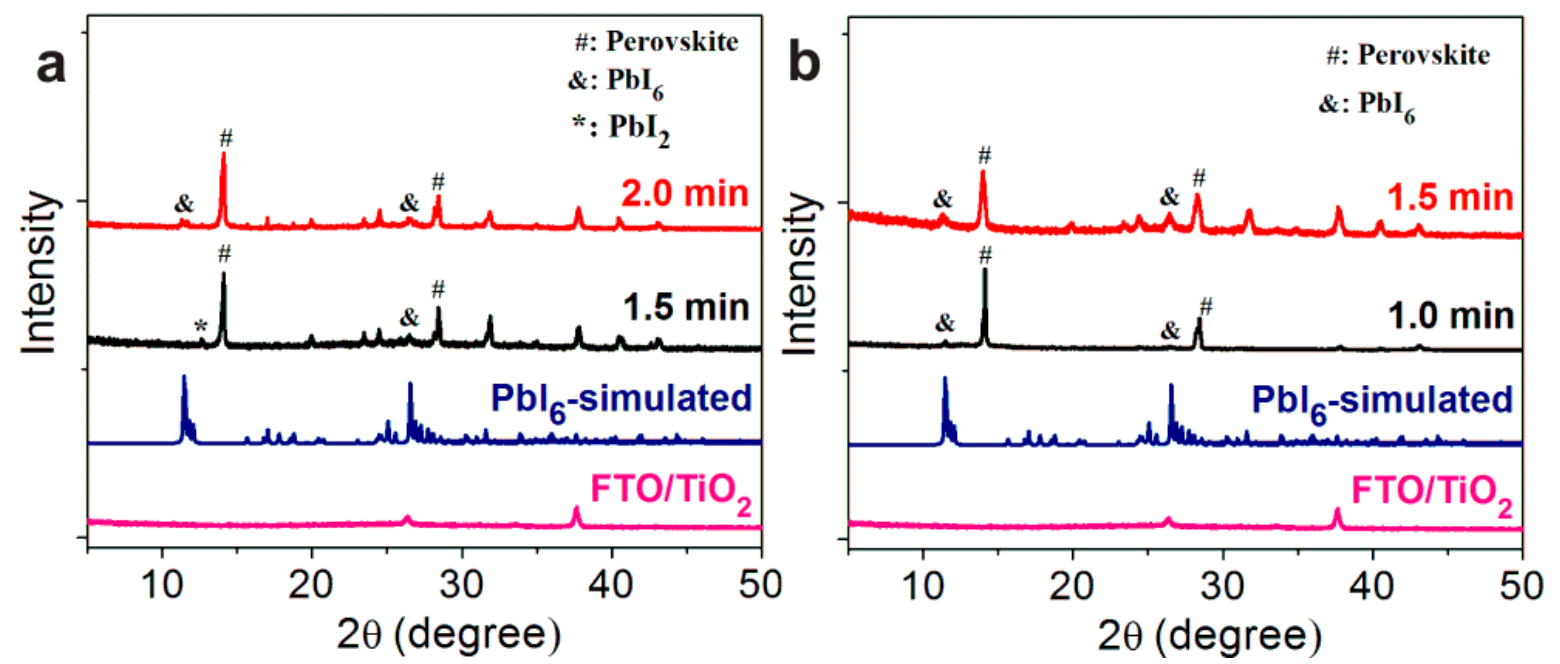

Figure S26. The XRD spectra of the mesoporous $\mathrm{Pbl}_{2}$ film immersed into a hot MAI solution with $10 \mathrm{mg} / \mathrm{mL}$ (a) and $50 \mathrm{mg} / \mathrm{mL}$ (b) at $70{ }^{\circ} \mathrm{C}$ for different time.

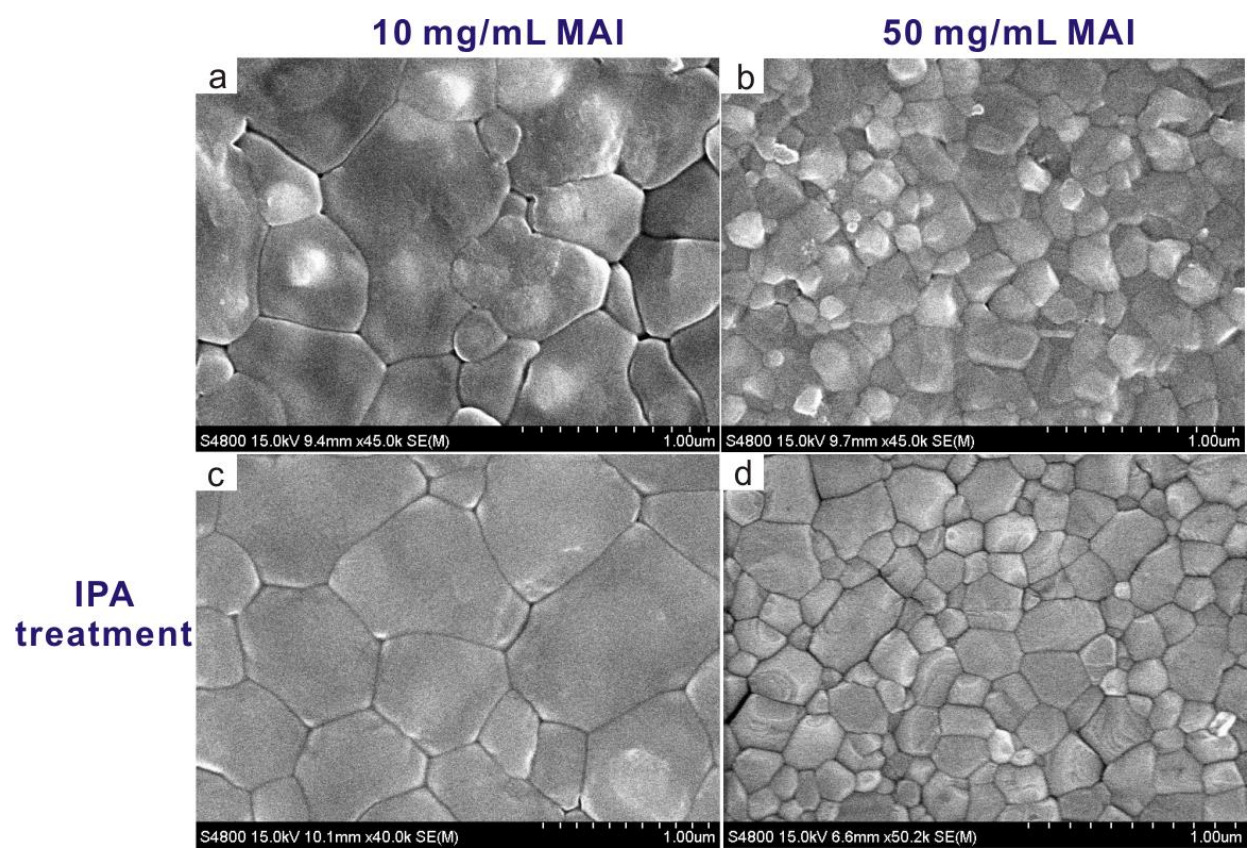

Figure S27. SEM images of the films of perovskite films by reaction of mosoporous $\mathrm{Pbl}_{2}$ and MAI with $10 \mathrm{mg} / \mathrm{mL}$ about $2 \mathrm{~min}$ (a) and $50 \mathrm{mg} / \mathrm{mL}$ about $1 \mathrm{~min}$ (b) and then washed by IPA (c, d). 

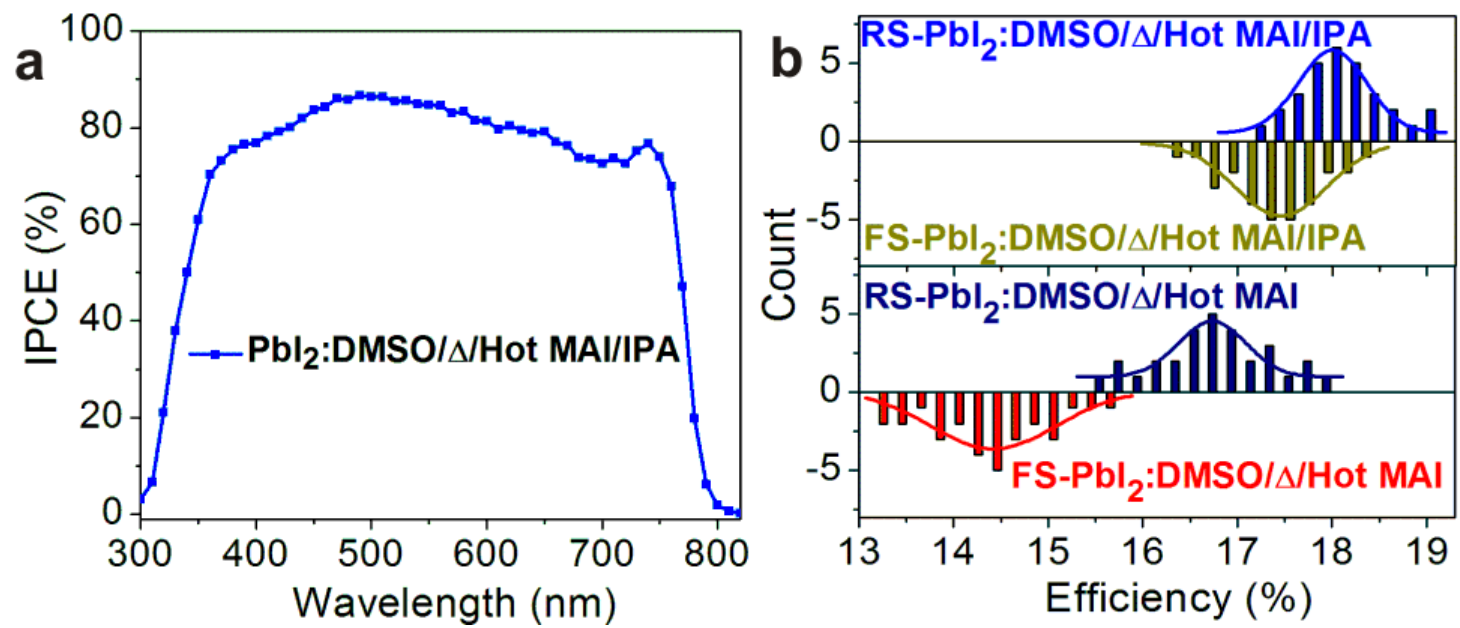

Figure S28. (a) The IPCE value of a PSC device by reaction of mesoporous $\mathrm{Pbl}_{2}$ with hot MAI followed by IPA washing. (b) Comparison of the performance distributions among 30 individual devices with or without employing IPA treatment measured by forward (FS) and reverse (RS) scans.

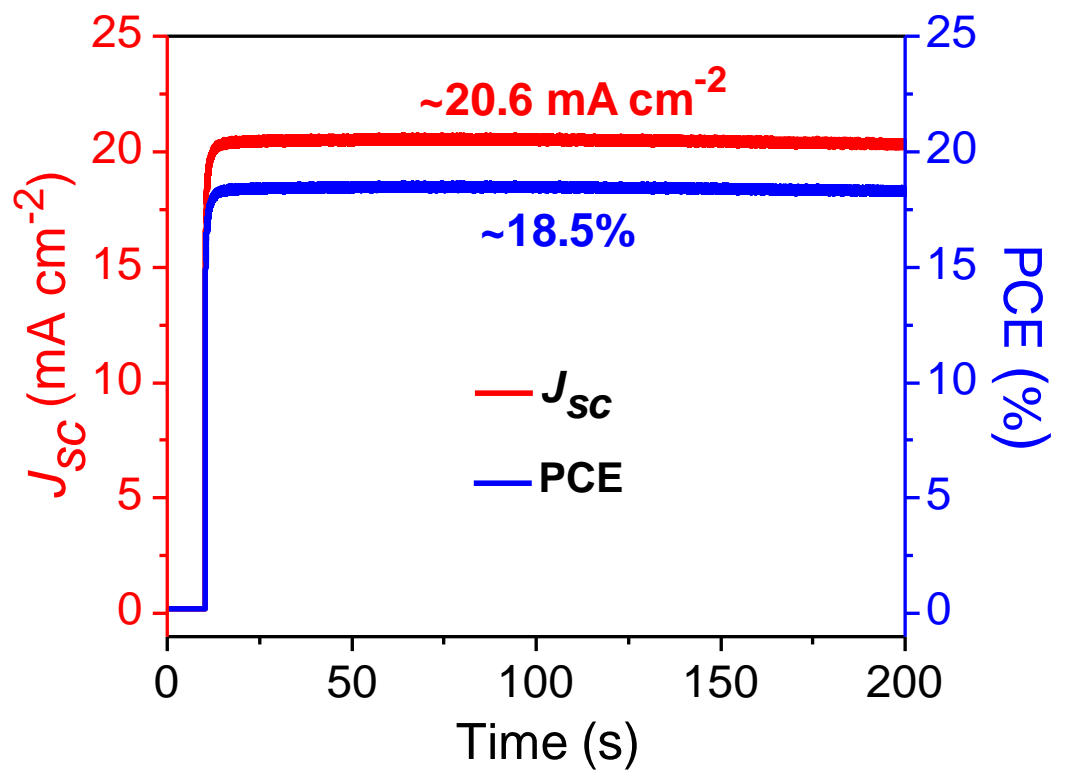

Figure S29. Stabilized power output of PCE and $J_{s c}$ at maximum power point (at $0.9 \mathrm{~V}$ bias) as a function of time for the cell under simulated AM 1.5 G solar light condition. 


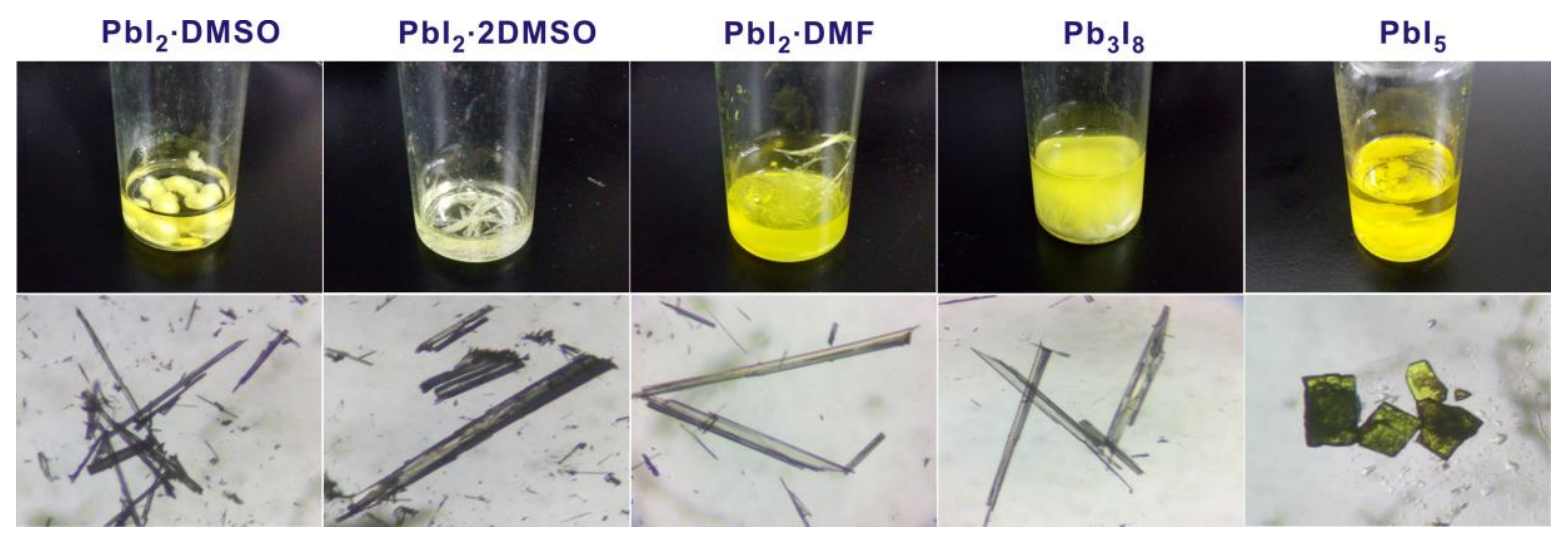

Figure S30. The photos of the obtained crystals in solution (Top row) and solid (Bottom row) state. 
Table S1. Photovoltaic parameters of the champion cells by one-step and two-step methods, and $\mathrm{Pb}_{3} \mathrm{I}_{8}$ precursor.

\begin{tabular}{ccccccc}
\hline \multicolumn{2}{c}{ Devices } & $J_{s d} \mathrm{~mA} \cdot \mathrm{cm}^{-2}$ & $V_{o d} \mathrm{~V}$ & $F F / \%$ & $\eta / \%$ & $R s / \Omega \cdot \mathrm{cm}^{-2}$ \\
\hline \multirow{2}{*}{ One step } & Reverse & 22.85 & 1.07 & 75.18 & 18.40 & 5.02 \\
& Forward & 22.61 & 1.07 & 73.66 & 17.82 & 5.04 \\
& Reverse & 22.65 & 1.07 & 74.04 & 18.00 & 6.03 \\
\multirow{2}{*}{ Two step } & Forward & 22.43 & 1.07 & 71.79 & 17.23 & 6.15 \\
& Reverse & 21.48 & 1.02 & 59.85 & 13.16 & 10.43 \\
$\mathrm{~Pb}_{3} \mathrm{I}_{8}$ & Forward & 21.78 & 0.96 & 46.10 & 9.60 & 12.15 \\
\hline
\end{tabular}

Table S2. Photovoltaic parameters of champion cells by the mesoporous $\mathrm{Pbl}_{2}$ films with different ration of DMSO.

\begin{tabular}{ccccccc}
\hline Devices & & $J_{s d} \mathrm{~mA} \cdot \mathrm{cm}^{-2}$ & $V_{\text {od }} \mathrm{V}$ & $F F / \%$ & $\eta / \%$ & $R s / \Omega \cdot \mathrm{cm}^{-2}$ \\
\hline & Reverse & 22.84 & 1.07 & 76.11 & 18.62 & 4.98 \\
$\mathrm{Pbl}_{2}$ :DMSO/A/drop MAI & & & & & & \\
& Forward & 22.82 & 1.07 & 74.06 & 18.06 & 5.21 \\
& Reverse & 22.88 & 1.07 & 74.69 & 18.29 & 5.03 \\
$\mathrm{Pbl}_{2}: 2 \mathrm{DMSO} / \Delta /$ drop MAI & Forward & 22.72 & 1.07 & 71.98 & 17.51 & 5.13 \\
\hline
\end{tabular}


Table S3. Photovoltaic parameters of the champion cells with different ratio of MAI.

\begin{tabular}{|c|c|c|c|c|c|c|}
\hline Devices & & $J_{s d} / \mathrm{mA} \cdot \mathrm{cm}^{-2}$ & $V_{o d} \mathrm{~V}$ & $F F / \%$ & $\eta / \%$ & $R s / \Omega \cdot \mathrm{cm}^{-2}$ \\
\hline \multirow{2}{*}{$\mathrm{Pbl}_{2}: \mathrm{DMSO}: \mathrm{MAl} / \Delta$} & Reverse & 22.85 & 1.07 & 75.18 & 18.40 & 5.02 \\
\hline & Forward & 22.61 & 1.07 & 73.66 & 17.82 & 5.04 \\
\hline \multirow{2}{*}{$\mathrm{Pbl}_{2}: \mathrm{DMSO}: 2 \mathrm{MAl} / \Delta$} & Reverse & 17.96 & 1.00 & 63.82 & 11.49 & 8.48 \\
\hline & Forward & 18.12 & 0.99 & 47.72 & 8.56 & 10.93 \\
\hline \multirow{2}{*}{$\mathrm{Pbl}_{2}: \mathrm{DMSO}: 2 \mathrm{MAl} / \Delta / \mathrm{IPA}$} & Reverse & 20.15 & 1.04 & 70.21 & 14.72 & 6.37 \\
\hline & Forward & 20.00 & 1.04 & 66.04 & 13.68 & 7.75 \\
\hline
\end{tabular}

Table S4. Photovoltaic parameters of the champion cell obtained by mesoporous $\mathrm{Pbl}_{2}$ and hot MAI solution followed by IPA washing.

\begin{tabular}{ccccccc}
\hline \multirow{2}{*}{ Devices } & & $J_{s d} \mathrm{~mA} \cdot \mathrm{cm}^{-2}$ & $V_{\text {od }} \mathrm{V}$ & $F F / \%$ & $\eta / \%$ & $R s / \Omega \cdot \mathrm{cm}^{-2}$ \\
\hline & & & & & & \\
\hline & Reverse & 22.96 & 1.08 & 76.61 & 19.01 & 4.92 \\
& Forward & 22.73 & 1.08 & 74.91 & 18.41 & 5.03 \\
\hline
\end{tabular}


Table S5. Crystal data and structure refinement for intermediates.

\begin{tabular}{|c|c|c|c|c|c|}
\hline Complexes & $\mathrm{Pbl}_{2} \cdot \mathrm{DMSO}$ & $\mathrm{Pbl}_{2} \cdot 2 \mathrm{DMSO}$ & $\mathrm{Pbl}_{2} \cdot \mathrm{DMF}$ & $\mathrm{Pb}_{3} \mathrm{I}_{8}$ & $\mathrm{Pbl}_{5}$ \\
\hline Formula & $\mathrm{C}_{2} \mathrm{H}_{6} \mathrm{I}_{2} \mathrm{O}_{2} \mathrm{PbS}$ & $\mathrm{C}_{4} \mathrm{H}_{12} \mathrm{I}_{2} \mathrm{O}_{2} \mathrm{PbS}_{2}$ & $\mathrm{C}_{3} \mathrm{H}_{7} \mathrm{l}_{2} \mathrm{NOPb}$ & $\mathrm{C}_{6} \mathrm{H}_{26} \mathrm{I}_{8} \mathrm{~N}_{2} \mathrm{O}_{2} \mathrm{~Pb}_{3} \mathrm{~S}_{2}$ & $\mathrm{C}_{5} \mathrm{H}_{25} \mathrm{I}_{5} \mathrm{~N}_{3} \mathrm{OPbS}$ \\
\hline $\mathrm{M} / \mathrm{g} \mathrm{mol}^{-1}$ & 555.12 & 617.25 & 534.09 & 1859.18 & 1229.01 \\
\hline $\mathrm{T} / \mathrm{K}$ & $99.97(11)$ & $100.01(10)$ & $100.01(10)$ & $100.01(10)$ & $100.01(10)$ \\
\hline Crystal system & Orthorhombic & Orthorhombic & Monoclinic & Orthorhombic & Monoclinic \\
\hline Space group & Pnam & Pccn & $\mathrm{P} 21 / \mathrm{n}$ & $\mathrm{Pbc} 21$ & C12/c1 \\
\hline$a / \AA ̊$ & 17.796(3) & 13.6978(4) & $4.53212(12)$ & $4.6212(6)$ & $20.641(2)$ \\
\hline$b / \AA ̊$ & $11.1352(17)$ & $10.8575(4)$ & $18.2385(5)$ & $27.219(7)$ & $12.4157(9)$ \\
\hline$c / \AA ̊$ & $4.5144(6)$ & $8.7607(3)$ & $11.5566(4)$ & $26.841(4)$ & $19.0841(19)$ \\
\hline$\alpha / \operatorname{deg}$ & 90 & 90 & 90 & 90 & 90 \\
\hline$\beta / \mathrm{deg}$ & 90 & 90 & $92.661(3)$ & 90 & $113.122(12)$ \\
\hline y/deg & 90 & 90 & 90 & 90 & 90 \\
\hline$V / \AA^{3}$ & $894.6(2)$ & $1302.93(7)$ & $954.23(5)$ & $3376.2(12)$ & $4497.9(8)$ \\
\hline Z & 4 & 4 & 4 & 4 & 8 \\
\hline $\mathrm{d}_{\mathrm{cal}} / \mathrm{g} \mathrm{cm}^{-3}$ & 4.122 & 3.147 & 3.718 & 3.658 & 3.004 \\
\hline & $-23<=\mathrm{h}<=22$ & $-13<=\mathrm{h}<=17$ & $-5<=\mathrm{h}<=5$ & $-4<=\mathrm{h}<=5$ & $-19<=\mathrm{h}<=23$ \\
\hline Limiting indices & $\begin{array}{c}-14<=\mathrm{k}<=13 \\
-5<=\mid<=3\end{array}$ & $\begin{array}{c}-14<=\mathrm{k}<=10 \\
-11<=\mid<=8\end{array}$ & $\begin{array}{c}-23<=\mathrm{k}<=23 \\
-14<=\mid<=8\end{array}$ & $\begin{array}{l}-35<=\mathrm{k}<=24, \\
-24<=\mid<=34\end{array}$ & $\begin{array}{l}-9<=\mathrm{k}<=14, \\
-22<=\mid<=20\end{array}$ \\
\hline $\begin{array}{l}\text { Reflections } \\
\text { collected / } \\
\text { unique }\end{array}$ & $\begin{array}{c}4831 / 1155 \\
{[R(\text { int })=0.1243]}\end{array}$ & $\begin{array}{c}5480 / 1494 \\
{[R(\text { int })=0.0417]}\end{array}$ & $\begin{array}{c}5104 / 2181 \\
{[R(\text { int })=0.0473]}\end{array}$ & $\begin{array}{c}12496 / 5166 \\
{[R(\text { int })=0.0645]}\end{array}$ & $\begin{array}{c}8115 / 2303 \\
{[R(\text { int })=0.0913]}\end{array}$ \\
\hline $\begin{array}{c}\text { Goodness-of-fit } \\
\text { on } F^{2}\end{array}$ & 1.102 & 1.070 & 1.048 & 1.060 & 1.180 \\
\hline Final $R$ indices & $R_{1}=0.0617$ & $R_{1}=0.0274$ & $R_{1}=0.038$ & $R_{1}=0.0602$ & $R_{1}=0.0827$ \\
\hline$[I>2 \sigma(I)]$ & $w R_{2}=0.1406$ & $w R_{2}=0.0663$ & $w R_{2}=0.088$ & $w R_{2}=0.1809$ & $w R_{2}=0.2290$ \\
\hline
\end{tabular}

